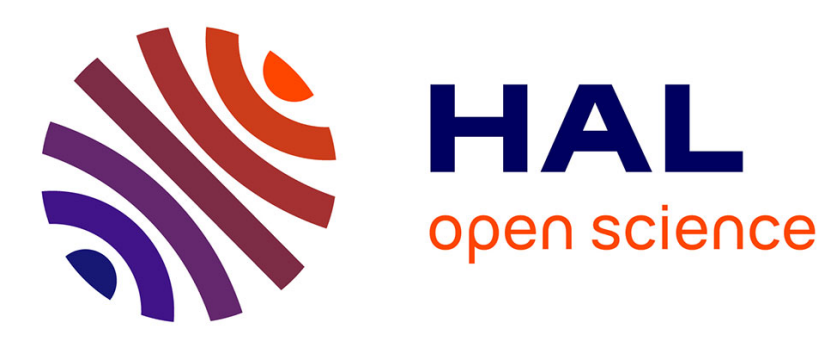

\title{
The North Cycladic Detachment System
}

Laurent Jolivet, Emmanuel Lecomte, Benjamin Huet, Yoann Denèle, Olivier

Lacombe, Loic Labrousse, Laetitia Le Pourhiet, Caroline Mehl

\section{To cite this version:}

Laurent Jolivet, Emmanuel Lecomte, Benjamin Huet, Yoann Denèle, Olivier Lacombe, et al.. The North Cycladic Detachment System. Earth and Planetary Science Letters, 2010, 289, pp.87-104. 10.1016/j.epsl.2009.10.032 . hal-00443755

\section{HAL Id: hal-00443755 \\ https://hal.science/hal-00443755}

Submitted on 5 Jan 2010

HAL is a multi-disciplinary open access archive for the deposit and dissemination of scientific research documents, whether they are published or not. The documents may come from teaching and research institutions in France or abroad, or from public or private research centers.
L'archive ouverte pluridisciplinaire HAL, est destinée au dépôt et à la diffusion de documents scientifiques de niveau recherche, publiés ou non, émanant des établissements d'enseignement et de recherche français ou étrangers, des laboratoires publics ou privés. 


\title{
The North Cycladic Detachment System
}

\author{
Laurent Jolivet a, b ${ }^{\text {, Emmanuel Lecomte }}{ }^{\mathrm{a}}$, Benjamin Huet ${ }^{\mathrm{a}}$, Yoann Denèle ${ }^{\mathrm{a}}$, Olivier \\ Lacombe $^{a}$, Loïc Labrousse ${ }^{a}$, Laetitia Le Pourhiet ${ }^{a}$ and Caroline Mehl ${ }^{c}$ \\ a ISTEP, UPMC-Paris6, UMR 7193, T 46-00 E1, 4 Place Jussieu, 75252 Paris Cedex 05, \\ France \\ b ISTO, Université d'Orléans-CNRS (UMR 6113), Campus Géosciences, 1A Rue de la \\ Férollerie, 45071 Orléans Cedex 2, France \\ ${ }^{\mathrm{c}}$ Ecole des Mines de Paris, Centre de Géosciences, 35 rue Saint Honoré, 77300 \\ Fontainebleau, France
}

\begin{abstract}
Low-angle normal faults accommodate a large part of continental post-orogenic extension. Besides the intrinsic rheological characteristics of the continental crust that may lead to the formation of shallow-dipping shear zones at the brittle-ductile transition, the role of preexisting low-angle structures such as large thrusts has been proposed by several authors. We explore this question with the example of the North Cycladic Detachment System (NCDS) that is composed of a series of distinct detachments cropping out on the islands of Andros, Tinos and Mykonos, separating the Cycladic Blueschists in the footwall from the Upper Cycladic Nappe in the hanging wall. We show that these extensional structures are part of a single large-scale structure (more than $200 \mathrm{~km}$ along strike) that reactivates the Vardar suture zone. It extends eastward on Ikaria and westward offshore Evia and Thessalia where it probably connects to recent shallow-dipping normal faults evidenced on published seismic reflection profiles. The NCDS started its activity in the Oligocene concommitantly with the Aegean extension, and was still active in the Late Miocene. It has exhumed a series of metamorphic domes from southern Evia to Mykonos below low-angle detachment systems, made of low-angle normal faults and low-angle ductile shear zones. The ductile shear zones and the faults were created with a low dip and they kept the same attitude throughout their exhumation. We identify three main detachments that are part of a continuum of extension on the NCDS : Tinos detachment, Livada detachment and Mykonos detachment. A fourth detachment (Vari detachment) is the reactivation of an Eocene exhumation-related structure. Deformation in the footwall is characterized by intense stretching and flattening. Using the spatial evolution observed along strike from Andros to Mykonos we construct a history of formation of the NCDS starting with the reactivation of former thrusts leading to the exhumation of high-temperature metamorphic domes. The Aegean example shows that reactivation of earlier shallow-dipping discontinuities can play a fundamental role in continental post-orogenic extension.
\end{abstract}

Keywords: Aegean Sea; Cyclades; detachment; backarc extension; brittle-ductile transition; gneiss dome 


\section{Introduction}

Low-angle normal faults and extensional shear zones play an important part in the extension of continental crust in post-orogenic ${ }^{1}$ contexts ([Crittenden et al., 1980], [Wernicke, 1981] and [Coney and Harms, 1984]). The origin of such low-dipping extensional structures is debated because they are a priori incompatible with the classical Andersonian theory. Several types of models have been developed between end-members with (1) passive rotation of the fault after it has ceased its activity (Buck, 1988), and (2) an initial low dip permitted by a weak rheology ([Lister and Davis, 1989] and [Collettini et al., 2009]), or stress rotation within the shear zone ([Melosh, 1990] and [Chéry, 2001];). A partly different explanation is the reactivation of earlier shallow-dipping heterogeneities such as large-scale thrust faults ([Jarrige, 1992] and [Patel et al., 1993]). In the Mediterranean region this hypothesis has been explored for instance in the Corinth Rift ([Le Pourhiet et al., 2004] and [Le Pourhiet et al., 2006]) or the Liguro-Provençal Basin (Rollet et al., 2002). At a larger scale, suture zones can sometimes localize lithospheric-scale extensional structures such as the Central Atlantic Rift (Piqué and Laville, 1996) or the Baikal Rift ([Delvaux et al., 1995], [Zorin, 1999] and [Petit and Deverchère, 2006]).The Aegean is a key-region to address this question. Post-orogenic extension in the Aegean Sea started some 30-35 Ma ago in the backarc region of the retreating Hellenic subduction zone (Jolivet and Faccenna, 2000). The most recent (post-5 Ma) phase of extension involved a combination of localized grabens, such as the Corinth Rift in Greece (Armijo et al., 1996), the Alasehir-Gediz graben in Turkey, and a large-scale strike-slip fault, the North Anatolian Fault ([Eyidogan and Jackson, 1985], [Armijo et al., 1996], [Armijo et al., 2002] and [Bozkurt and Sözbilir, 2004]), but most of the extension was achieved earlier with a more widely distributed deformation (Fig. 1). Extension during this period between the Oligocene and the Pliocene led to the formation of the Cycladic metamorphic core complexes and associated detachments ([Lister et al., 1984], [Gautier and Brun, 1994a] and [Jolivet et al., 2004a]). Even if the term "detachment” has been used in different structural contexts, including thrusting, it refers most often to a low-angle normal fault. Although the term “decollement” would sometimes seem more appropriate (see a discussion in Ramsay and Huber, 1987), “detachment” has also been used to describe almost horizontal shear zones following rheological discontinuities, as discussed in Wernicke (1995). It has also been used ("megadetachment") to refer to a horizontal shear zone decoupling the crust from the mantle below the western United States (Wernicke et al., 2008). In this paper we used detachment as a low-angle extensional system, including low-angle normal faults in the brittle regime and low-angle extensional shear zones in the ductile regime.

Several individual detachments have been described since the first paper reporting a Cordilleran-type metamorphic core complex in this region (Lister et al., 1984). The northern Cyclades detachments were so far described as separate entities. On the single island of Tinos several detachments have been reported that were active at different periods (Brichau et al., 2007). We present a synthesis of available observations on the northern Cycladic Islands and propose an integrated picture. We show that all these structures are part of a single crustalscale detachment, here after called the North Cycladic Detachment System (NCDS), that partly reactivated the Vardar oceanic suture zone.

\subsection{Geological setting}

The Cycladic archipelago lies in the center of the Aegean Sea (Fig. 2) in an area that is currently seismically quiet, whereas the surrounding regions are characterized by an intense 
active seismicity ([Jackson and McKenzie, 1984] and [Taymaz et al., 1991]). Extension started in the Late Oligocene above the subduction zone, mainly as a consequence of slab retreat ([Le Pichon and Angelier, 1979], [Le Pichon and Angelier, 1981] and [Jolivet and Faccenna, 2000]). It is presently localized in the external Hellenic arc, in western Turkey, in southeastern continental Greece, in northern Greece and along the North Aegean Trough that represents the extension of the dextral strike-slip North Anatolian Fault in the Aegean domain (Fig. 1). Before the Pliocene, extension was accommodated by a series of detachments, in the footwall of which several metamorphic core complexes were exhumed ([Lister et al., 1984], [Gautier and Brun, 1994a] and [Jolivet and Brun, in press]).

The Cycladic Islands rest upon a continental crust that was thinned to $26 \mathrm{~km}$ in the Oligocene and the Miocene after the formation of the Hellenic Belt in the Eocene ([Vigner, 2002], [Tirel et al., 2004b] and [Karagianni et al., 2005]). The Moho discontinuity is rather flat below the whole archipelago, suggesting a low viscosity lower crust and a high Moho temperature at the time of extension (Tirel et al., 2004a). The Hellenic Belt was formed by stacking of the upper crustal units within an accretionary wedge with SW-verging thrusts from the Eocene to the Late Miocene in continental Greece ([Brunn et al., 1976], [Jacobshagen et al., 1978], [Bonneau and Kienast, 1982], [Doutsos et al., 1993], [Sotiropoulos et al., 2003], [Ring et al., 2001], [Ring et al., 2007b], [Vanderhaeghe and Teyssier, 2001] and [Vanderhaeghe et al., 2007]). In the Aegean Sea the beginning of slab retreat some 30-35 Ma ago led to postorogenic extension of the Hellenic thickened crust by a combination of backarc extension and gravitational collapse (Jolivet and Brun, in press). Post-orogenic extension reworked the nappe stack and the various nappes were redistributed within the Aegean Sea (Fig. 2). The original vertical organisation of the nappe stack was however often preserved and one can recognize the original superposition of nappes ([Bonneau, 1984] and [Jolivet et al., 2004b]).

From top to base one can recognize the following units. (1) The uppermost unit observed in the Cyclades is the Upper Cycladic Nappe, an equivalent of the Pelagonian nappe in the Hellenides. The Pelagonian nappes are thus found from continental Greece to the Cyclades and as far as Crete at the top of the edifice ([Reinecke et al., 1982], [Bonneau, 1984] and [Papanikolaou, 1987]). On the three islands considered in this paper (Andros, Tinos and Mykonos) is essentially made of ophiolitic material (serpentinite, gabbros and basalts) belonging to the Vardar suture zone but other islands show continental basement in the Pelagonian domain units (Syros, Donoussa...). High-temperature gneiss and amphibolites with Late Cretaceous metamorphic ages are also locally observed (Maluski et al., 1987). This unit has not recorded the Eocene high-pressure and low-temperature ( $\mathrm{H} P-\mathrm{L} T)$ metamorphic event and it was thus already in the upper crust during the formation of the Hellenides in the Eocene. (2) The Upper Cycladic Nappe overlies the Cycladic Blueschists, a composite unit with a significant component of metabasic rocks included in metapelites and marbles ([Blake et al., 1981], [Avigad and Garfunkel, 1991] and [Keiter et al., 2004]). Ages of the protolith range from the Triassic to the Cretaceous (Bröcker and Pidgeon, 2007). It is generally considered a lateral equivalent of the Pindos oceanic zone in the Hellenides (Bonneau, 1984). It differs from the Vardar ocean that was located north of the Pelagonian domain. It is composed of several superposed units, including a mafic olistostrome well exposed on Syros island (Keiter et al., 2004). The Cycladic Blueschists show a complex metamorphic evolution, with an early burial in $\mathrm{H} P-\mathrm{L} T$ conditions (blueschists and eclogites) during the Eocene followed by a HT-LP overprint during the Oligocene and Miocene ([Altherr et al., 1979], [Altherr et al., 1982], [Wijbrans and McDougall, 1986] and [Wijbrans and McDougall, 
1988]). (3) The Cycladic basement crops out on the islands of Paros, Naxos, Mykonos and Ios. Ios shows overthrusting relations between the Cycladic Blueschists in the hanging wall of a major shear zone and the basement in the footwall (Huet et al., 2009). This thrust was originally interpreted as a detachment with a top-to-the-south sense of shear (Vandenberg and Lister, 1996). Radiometric ages show that top-to-the-south shear bands (thrust related in the

interpretation of Huet et al., 2009) were active at 35 Ma and before and that they were replaced by top-to-the-north shears at around $25 \mathrm{Ma}$ (Foster and Lister, 2009). No evolution is observed toward HT conditions in the Oligocene and Miocene, at variance with the nearby islands of Paros, Naxos and Mykonos where amphibolite-facies metamorphism and anatexis are dated of the Late Oligocene-Early Miocene (Altherr et al., 1982). In this case the basement is exhumed in the core of extensional gneiss domes below the main detachments ([Buick and Holland, 1989], [Buick, 1991a], [Keay et al., 2001], [Duchêne et al., 2006] and [Martin et al., 2006]). Syn-tectonic Miocene granites intrude the domes in Naxos, Mykonos, Serifos and Ikaria ([Jansen, 1973], [Lee and Lister, 1992], [Altherr and Siebel, 2002], [Grasemann and Petrakakis, 2007] and [Iglseder et al., 2009]).

The brittle detachments are localized at the base of the Upper Cycladic Nappe, at the contact with the Cycladic Blueschists, the basement, or the granites. Two types of detachments can be distinguished. The most common ones are those showing an Oligo-Miocene evolution toward $\mathrm{H} T$ in their footwall or at least a strong retrogression of $\mathrm{H} P-\mathrm{L} T$ parageneses in the greenschists facies ([Buick and Holland, 1989], [Parra et al., 2002], [Jolivet et al., 2004a] and [Duchêne et al., 2006]). They are found on the islands of Andros, Tinos, Mykonos, Ikaria, Paros and Naxos, associated with a top-to-the-north or -northeast sense of shear ([Faure et al., 1991], [Lee and Lister, 1992], [Gautier et al., 1993], [Gautier and Brun, 1994a] and [Mehl et al., 2007]). The detachment itself is not always present but similar footwall evolution is observed in the western Cyclades with however an opposite shear sense. Serifos shows outcrops of the detachment and serpentinites of the Upper Cycladic Nappe in small peninsulas to the southwest and northeast of the island ([Grasemann and Petrakakis, 2007] and [Brichau et al., 2009]). A top-to-the-southwest sense of shear, interpreted as extensional, is observed in a low-angle mylonite derived from a 37 Ma old intrusion. A late Miocene granitoid, dated at 8-9 Ma ([Altherr et al., 1982] and [Henjes-Kunst et al., 1988]) intrudes the mylonite and is also affected by a top-to-the-southwest shearing (Grasemann and Petrakakis, 2007 ). Kea and Kythnos also show a top-to-the-southwest sense of shear but the Upper Cycladic Nappe is absent. They formed contemporaneously with backarc extension. The second type shows instead a good preservation of $\mathrm{H} P-\mathrm{L} T$ parageneses in their footwall, the closer from the detachment the better preserved the eclogites and blueschists ([Trotet et al., 2001a] and [Trotet et al., 2001b]). Such detachments are found principally on the islands of Syros and Tinos (Vari detachment). They were active in the Eocene when they accommodated the exhumation of eclogites and blueschists in the subduction channel (Jolivet and Brun, in press) or in an extrusion wedge ([Ring et al., 2001], [Ring et al., 2007a] and [Ring and Layer, 2003]).

A gradient of finite extension is shown by the evolution of topography and crustal thickness from continental Greece to the Cyclades (Jolivet et al., 1994). The main structures of the Hellenides are preserved in continental Greece while they are highly reworked by extension in the Cyclades. This gradient is associated with the maximum retrograde temperature gradient observed in the Cycladic Blueschists from Mt Olympos to Naxos and Mykonos (Jolivet and Patriat, 1999). Along this transect an evolution of Oligo-Miocene extensional structures is 
also observed, from essentially brittle structures (steep normal faults) near Mount Olympos to ductile shear zones and shallow-dipping detachments in Evia and the Cyclades.

\section{The North Cycladic Detachment System}

The North Cycladic Detachment System (NCDS) is a single crustal-scale structure that includes several detachments observed on different islands of the Northern Cyclades and described so far as separates entities. We now focus on the four islands of Andros, Tinos, Mykonos and Syros (Fig. 3 and Fig. 4). The three major units of the Cyclades are represented on these islands, Upper Cycladic Nappe, Cycladic Blueschists and the Cycladic basement. Andros shows small remnants of the Upper Cycladic Nappe along its northeastern coast as greenschists and serpentinite ([Papanikolaou, 1977] and [Mehl et al., 2007]). The rest of the island is made of the Cycladic Blueschists folded in a broad NW-SE trending antiform. Tinos is mostly made of the Cycladic Blueschists and of the Upper Cycladic Nappe that crops out in large domains along the northeastern and southwestern coasts ([Melidonis, 1980] and [Katzir et al., 1996]). An additional unit on Tinos is considered an equivalent of the Triassic part of the Gavrovo-Tripolitza nappe lying below the Pindos unit in continental Greece (Avigad and Garfunkel, 1989). Sometimes considered as a non-metamorphic unit it actually shows metamorphic recrystallisation in the metaflysch above the Triassic marbles. It can be considered as the cover of the Cycladic basement. At 14-15 Ma a granite intruded both the Cycladic Blueschists and the Upper Cycladic Nappe on Tinos ([Altherr et al., 1982], [Avigad and Garfunkel, 1989], [Bröcker and Franz, 1994] and [Brichau et al., 2007]). Mykonos is mostly made of a granite with an intrusion age at around $13 \mathrm{Ma}$ ([Altherr et al., 1982] and [Brichau et al., 2008]). The western part of the island as well as the neighbouring islands of Delos and Rhinia are made of gneiss and migmatites ([Faure et al., 1991] and [Lucas, 1999]). A series of small klippes of the Upper Cycladic Nappe, mostly metabasites, crops out in the eastern part of the island. Detrital sediments, sandstones and conglomerates, form the uppermost unit on Mykonos, and similar sediments are found on Paros and Naxos ([SanchezGomez et al., 2002] and [Kuhlemann et al., 2004]). The conglomerate mostly contains pebbles issued from the Upper Cycladic Nappe suggesting that it once covered most of the area. It also contains reworked volcanic rocks and granites as young as $10 \mathrm{Ma}$ (SanchezGomez et al., 2002) but clasts issued from the Cycladic Blueschists are not found. The Cycladic Blueschists were therefore finally exhumed to the surface late in the history of the core complexes.

Several detachment surfaces were described in the literature ([Avigad and Garfunkel, 1989], [Faure et al., 1991], [Gautier et al., 1993], [Gautier and Brun, 1994b], [Patriat and Jolivet, 1998], [Jolivet et al., 1999], [Kumerics et al., 2005], [Brichau et al., 2006], [Brichau et al., 2007] and [Brichau et al., 2008]). They are all localized at the base of the Upper Cycladic Nappe or at the base of the Miocene sediments. Across the Aegean Sea structures can be correlated using the lithologies and metamorphic evolutions of their footwalls and hanging walls. The detachments, except for the Vari detachment that was first active in the Eocene, all took part in the formation of the Aegean Sea from the Late Oligocene to the Late Miocene at various stages. In the following the major low-angle normal faults are described and their history inserted into the development of a large-scale detachment, the North Cycladic Detachment System. 


\subsection{Vari detachment}

The Vari detachment crops out on Syros and Tinos ([Trotet et al., 2001a] and [Ring et al., 2003]). The hanging wall is made of Late Cretaceous high-temperature metamorphic rocks, amphibolite-facies metabasites, gneiss and some serpentinites ([Katzir et al., 1996] and [Zeffren et al., 2005]). Several units, which are more and more retrograded downward, are recognized on Syros in the footwall. Well-preserved eclogites and blueschists are found only in the upper part of the footwall just below the detachment (Trotet et al., 2001a).

Metamorphic ages are all Eocene and they reflect the exhumation of the Cycladic Blueschists in the subduction channel ([Bonneau et al., 1980], [Maluski et al., 1987] and [Bröcker and Enders, 1999]). E-W-trending stretching lineations are observed on Syros with indication of a top-to-the-east shear sense during exhumation (Trotet et al., 2001a). This shearing deformation is coeval with the retrogression of eclogites in the blueschists-facies and of the blueschists in the greenschists-facies. The Vari detachment is found also on the southwestern side of Tinos ([Ring et al., 2003] and [Jolivet et al., 2004a]). Eclogites and blueschists are observed below, probably the best preserved of the whole island ([Melidonis, 1980] and [Parra et al., 2002]). They are devoid of the intense greenschist stretching and shearing found everywhere else on the island. The detachment itself does not crop out well. It shows some cataclastic deformations (Ring et al., 2003). Apatite and zircon fission-tracks data show a slow cooling since the Late Cretaceous for the hanging wall and a fast Late Miocene cooling for the footwall. The Late Miocene motion accounts for no more than 6-9 km of exhumation (Brichau et al., 2007) even if the detachment has accommodated $60 \mathrm{~km}$ of exhumation since the Eocene ([Trotet et al., 2001a] and [Jolivet et al., 2004a]). The part of the activity of the Vari detachment contemporaneous of the Aegean extension is thus minor compared to its Eocene history. The Vari detachment is thus mainly an Eocene structure that accommodated the exhumation of $\mathrm{H} P-\mathrm{L} T$ rocks in the subduction zone and that was reactivated in the Late Miocene. In our interpretation, it does not belong to the North Cycladic Detachment System proper.

\subsection{Tinos Detachment}

The Tinos Detachment is a continuous structure found from Andros to the southeastern tip of Tinos (Fig. 5 and Fig. 6). Its hanging wall is made of Upper Cycladic Nappe ophiolitic material, serpentinite, gabbros and minor basalts ([Patzak et al., 1994] and [Katzir et al., 1996]). Hanging wall rocks show little ductile deformation except close to the detachment itself, where a greenschist-facies foliation and lineation are locally observed (Zeffren et al., 2005). The footwall is intensely deformed with a gradient of shearing toward the detachment, upward and northeastward ([Patriat and Jolivet, 1998], [Jolivet et al., 1999], [Aubourg et al., 2000], [Jolivet et al., 2004a], [Mehl et al., 2005] and [Mehl et al., 2007]). The NE direction of stretching is consistent along the whole length of Andros and Tinos and the shear sense is toward the northeast (Fig. 4). The gradient of deformation suggests the presence of a crustalscale shear zone that was active in the Late Oligocene and Early Miocene. Available radiometric ages show that the greenschists retrogression contemporaneous with the top-tothe-NE shear started some 30 Ma ago (Bröcker, 1990 M. Bröcker, Blueschist-to-greenschist transition in metabasites from Tinos island, Cyclade, Greece: compositional control or fluid infiltration, Lithos 25 (1990), pp. 25-39. [Bröcker, 1990], [Bröcker and Franz, 1998] and [Parra et al., 2002]). The Tinos detachment is intruded by the granite; it must thus have achieved the major part of its displacement before approximately 14-15 Ma ([Avigad and Garfunkel, 1989] and [Brichau et al., 2007]). 
Both Andros and Tinos show a highly asymmetric distribution of deformation ([Jolivet et al., 2004a], [Mehl et al., 2005] and [Mehl et al., 2007]). The southwestern side of the islands shows an almost symmetrical finite strain illustrated by symmetrical boudins at all scales. Andros shows an evolution in the geometry of boudins from SW to NE, from symmetrical ones to totally asymmetrical ones in the NE below the detachment (Fig. 5). The deformation related to the Oligo-Miocene extension is thus distributed across the whole island and the detachment fault is localized above the most highly sheared part of the footwall. The domal shape of the foliation can be interpreted as a crustal-scale boudin bounded to the NE by the Tinos detachment. Tinos shows a similar evolution (Fig. 6) but with a higher shearing intensity and higher peak temperature during retrogression.

The detachment crops out in excellent conditions both on Andros and Tinos (Figs. 6 and 7). It is a shallow-dipping fault that is found either at the top or at the base of a thick layer of cataclasites. The cataclasites are formed at the expense of serpentinite and micaschists and show dense veining suggesting intense fluids circulation. These fluids, as well as those analysed in greenschist veins, have been shown to be of meteoric origin (Famin et al., 2004).

Minor normal faults are observed in the whole footwall ([Mehl et al., 2005] and [Mehl et al., 2007]) (Fig. 4). They show a direction of extension similar to the ductile one and the maximum principal stress axis is always vertical, even in the vicinity of the shallow-dipping detachment. These faults are coeval with vertical tension gashes connected to cataclasites suggesting that they are synchronous to the detachment activity. No rotation therefore occurred and the Tinos detachment was originally formed with a low dip.

The Tinos Detachment was thus active with a low dip between the Late Oligocene and the Middle Miocene. An evolution from ductile to brittle with a continuum in the direction of extension and the sense of shear shows that the footwall crossed the brittle-ductile transition during extension. The presence of cataclasites and evidence for intense meteoric fluid circulation in the damaged zone suggest that the detachment was a weak zone, that is compatible with the attitude of minor normal faults and veins that indicate a permanently vertical maximum principal stress axis. The shape of the foliation dome in Andros and Tinos and the evolution of the deformation across the dome are compatible with boudinage at crustal scale.

The hanging wall is most often devoid of extensional deformation except in the basal greenschists. The metagabbros and serpentinites do not show clear evidence of extensional shear zones and normal faults except in the vicinity of the granite where a high-temperature foliation and stretching lineation is recorded while normal faults and ductile extensional shear zones affect granitic and aplitic sills, suggesting that the deformation has migrated upward due to the intrusion of the granite. This reveals a second stage in the history of the NCDS, with the formation of the Livada Detachment.

\subsection{Livada Detachment}

The Livada Detachment is observed in the eastern part of Tinos and on Mykonos where the granites intrude the hanging wall metabasites (Fig. 7).

On Tinos the granite shows a rather high-temperature ductile deformation with a stretching lineation trending parallel to the regional one ([Faure et al., 1991], [Jolivet et al., 1999], [Habert, 2004] and [Brichau et al., 2007]). Minor discrete shear bands indicate a top-to-the- 
NE shear sense. The base of the hanging wall metabasites display a strong foliation and a stretching lineation marked by the elongation of white plagioclase in the amphibolitic matrix. Here also the shear sense is top to the northeast. This zone of ductile deformation is not thicker than a few tens of meters. Higher up, serpentinite and gabbros show a more localized deformation pattern that becomes locally brittle. It is very clearly displayed where granitic and aplitic sills have intruded the metabasites (Fig. 7). The metabasites are locally foliated and sheared as near the base of the unit, and shear and foliation planes are intruded by aplitic sills that present a sigmoidal shape. Minor normal faults affect the sills and they indicate a direction of extension similar to the regional one. The intrusion of the granite is thus synkinematic of the detachment. The asymmetry of the normal faults system is compatible with a top-to-the-northeast sense of shear.

On Mykonos the granite is almost entirely foliated with a shallow east-dipping foliation ([Faure et al., 1991], [Lee and Lister, 1992], [Gautier and Brun, 1994a], [Lucas, 1999] and [Brichau et al., 2008]). The deformation increases upward and eastward approaching the detachment. Two detachment surfaces are visible on the island, an equivalent of the Livada detachment below and the Mykonos detachment above (Lecomte et al., submitted) (Fig. 8, lower panel). The Livada Detachment shows some features already seen on Tinos. The contact between the granite and the upper plate metabasites is clearly intrusive as shown by metabasites rafts included in the granite. A foliation develops parallel to the contact with a gradient of intensity toward the contact. A conspicuous stretching lineation trends ENE in most of the island and turns to $\mathrm{NE}\left(\mathrm{N} 20^{\circ} \mathrm{E}\right)$ in the east near the detachment. It is associated with shear planes indicating a top-to-the-east or -northeast sense of shear. The density of the shear planes increases when approaching the contact. Ultramylonite bands also form and their density increases in the same direction. Ductile deformation is also observed at the base of the metabasites and the mylonitic contact is folded with asymmetric folds compatible with the top-to-the-northeast shear sense. Aplitic sills intrude the metabasites and they are cut by shallow and steeply east-dipping normal faults that root on the foliated contact. This geometry and kinematics are thus very similar to what has been observed on Tinos island. Considering the slight age difference between the two granites it could be argued that the two shear zones are different in age, but for the sake of simplicity we prefer to consider them as a single structure, slightly younging toward the SE.

The Livada Detachment is thus mainly a ductile structure at the upper contact of the two granitic plutons when they intrude the hanging wall of the Tinos Detachment. The effect of the intrusion is to locally lift the brittle-ductile transition upward within the hanging wall and a shear zone localizes at the contact between the two lithologies with a kinematics similar to the regional one (Jolivet and Patriat, 1999).

\subsection{Mykonos Detachment}

The uppermost detachment is localized at the base of the Late Miocene sediments cropping out on Mykonos (Skarpelis, 2002; Lecomte et al., submitted) (Fig. 8, upper panel). The sediments rest through the detachment either on top of the cataclastic granite like in Panormos Bay or on top of the Upper Cycladic Nappe metabasites like around Cape Evros (Vathia Langada) in the easternmost part of the island. The detachment itself is a clearcut fault plane dipping $12-15^{\circ}$ to the NE. It carries a dip-slip striae and some plurimetric-scale corrugation parallel to the sense of slip. Several levels of cataclasites derived from the granite or the metabasites underlie the fault plane and a thick level of a very coarse sedimentary breccia is observed above the detachment in the east (Fig. 9). The breccia is made of metamorphic rocks 
clasts and it grades upward into finer grained stratified sediments (Skarpelis, 2002). The molassic sediments are invaded by large vertical veins of barite and Fe-hydroxydes that also cut the detachment and the granite. The basal breccia is largely silicified and mineralized. The veins strike perpendicular to the direction of ductile shear in the granite and to the slip direction on the detachment plane, suggesting that they were formed in the same continuum of NE-SW extension. Sediments dip toward the SW and dips can locally reach $30-40^{\circ}$, but the average is around $15-20^{\circ}$. Evidence for roll-over structures is found in Panormos Bay and soft-sediment deformation is observed in the vicinity of steep normal faults rooting in the detachment. All these observations suggest that the detachment was active with a low dip quite close to the surface (Lecomte et al., submitted). The basal breccia is in places pinched out and the sheared finer grain sediments rest directly on top of the detachment plane.

The Mykonos Detachment was thus formed above the Livada Detachment and it involves less ductile structures. It appears contemporaneous with the deposition of conglomerates and sandstones. The presence of soft-sediment deformation associated with normal faults rooting in the detachment shows that these faults were formed at a very shallow crustal level whereas the thick cataclasites and the ductile deformation observed below were formed in deeper parts of the crust (Fig. 9).

To summarize, some 13 Ma ago, a granite impinged the base of the brittle crust that was cut by a shallow-dipping detachment (the Tinos detachment). The granite intruded the brittle crust and the detachment itself. The brittle-ductile transition was uplifted following the intrusion of the granite and detachments migrated upward along the rheological contrast between the granite and the metabasites. The intrusive contact was sheared below the lowermost detachment (the Livada Detachment) and granitic sills and dykes were cut by shallow-dipping and steeply-dipping normal faults. The uppermost detachment (the Mykonos Detachment) might have been formed slightly after the Livada detachment once the granite had cooled down and hardened. This detachment brought the syn-tectonic sediments close to the metabasites and eventually, close to the granite, through a thick zone of cataclasites, showing a significant offset along the Mykonos detachment.

\section{The NCDS: a scenario}

The Tinos, Livada and Mykonos Detachments bear similarities in terms of attitude and shear sense. They developped sequentially in time and they affected different crustal levels.

Estimations of the finite displacements along these structures are quite variable. A high value of $70 \mathrm{~km}$ along dip was proposed for the Tinos detachment since $30 \mathrm{Ma}$ (see a discussion in Jolivet et al., 2004a). The Tinos Detachment, between the Cycladic Blueschists and the Upper Cycladic Nappe acted principally in the ductile field and only the end of motion was achieved in the brittle field, with an important role played by cataclastic flow (Mehl et al., 2005) before the Tinos granite intruded and sealed it. One must furthermore distinguish between synorogenic exhumation (before $30 \mathrm{Ma}$ ) and post-orogenic exhumation (after $30 \mathrm{Ma}$ ). Most of the syn-orogenic exhumation was actually achieved before $37 \mathrm{Ma}$ (Jolivet et al., 2004a), and it corresponds to a vertical displacement of approximately $30 \mathrm{~km}$ based on the shape of the P-Ttime path. $20 \mathrm{~km}$ of vertical movement completed the exhumation during the post-orogenic stage. Exhumation along the low-angle Tinos detachment was completed before the intrusion of the Tinos granite at $14 \mathrm{Ma}$ that sealed the contact between the upper and lower units. The most superficial ductile deformation is constrained by the last $\mathrm{P}-\mathrm{T}$ points recorded along the $\mathrm{P}-\mathrm{T}$ path (Parra et al., 2002) at some $2 \mathrm{kbar}$ or $7 \mathrm{~km}$, a value that is compatible with 
independant estimates of intrusion depth at $7 \mathrm{~km}$ ([Bröcker and Franz, 1994], [Bröcker and Franz, 2000] and [Stolz et al., 1997]). Estimating the amount of slip along the Tinos detachment is not straightforward because the vertical movement was partitioned between pure shear distributed within the Cycladic Blueschist and simple shear along the main shear zone. Nothing actually unambiguously constrains the respective contributions of both components of the strain. Assuming that most of the displacement was achieved by simple shear gives a maximum figure on the amount of slip that amounts to $60-70 \mathrm{~km}$ on a $20^{\circ}$ dipping detachment, and anything between 30 and $50 \mathrm{~km}$ seems reasonable. $30 \mathrm{~km}$ was estimated for the Mykonos detachment since the emplacement of the Mykonos granite some $13 \mathrm{Ma}$ ago, and $10 \mathrm{~km}$ for the Livada Detachment between 14 and $10 \mathrm{Ma}$ ([Brichau et al., 2006], [Brichau et al., 2007] and [Brichau et al., 2008]). The Livada Detachment, between the Tinos and Mykonos granites and the Upper Cycladic Nappes, was mainly ductile and localized along the intrusive contact. The Mykonos Detachment, at the base of Late Miocene syn-rift sediments, is principally brittle with an important role devoted to cataclasites and it provides evidence of motion at shallow crustal levels. In all three cases there is no clear evidence that the detachment has been significantly tilted after its formation. These evidences are (1) a systematically vertical $\sigma_{1}$ deduced from the inversion of fault data even with shallowdipping minor faults ([Mehl et al., 2005] and [Mehl et al., 2007]), (2) systematically vertical veins, (3) no rotation shown by palaeomagnetic data on Tinos (Avigad et al., 1998), and (4) the attitude of syn-tectonic sediments on Mykonos that show no significant tilt (this work and Lecomte et al., submitted).

Paleomagnetic studies have been used to suggest that the Tinos detachment has not been tilted (based on the absence of any inclination anomaly of vertical volcanic dykes and of the granite) and the Mykonos Detachment has, on the contrary, been tilted by some $50^{\circ}$ (strong inclination anomaly) before a vertical axis rotation (Avigad et al., 1998). This conclusion is based upon palaeomagnetic data obtained independantly in the least deformed part of the pluton (Morris and Anderson, 1996). A closer look at the stretching lineation reveals that it strikes $\mathrm{N} 70^{\circ} \mathrm{E}$ over most of the island and that it turns to $\mathrm{N} 20^{\circ} \mathrm{E}$ when approaching the detachment in the east of the island. $\mathrm{N} 20^{\circ} \mathrm{E}$ is the regional stretching direction after correction from vertical axis rotations in Morris and Anderson (1996). This observation suggests that the pluton has suffered differential rotations between the upper part, close to the detachment and the more rigid part deeper down (Lecomte et al., submitted). The strong tilting being hardly compatible with the orientation of normal faults and veins above the detachment, and the Livada Detachment having the same characteristics in Tinos and Mykonos, we consider that no major tilting affected the Mykonos Detachment.

The similarities observed between the different detachments and the evolution in space and time of the localization of the main movement zone suggest a single crustal-scale structure that we name the Northern Cycladic Detachment System. This structure reworked the Hellenic accretionary wedge from the Late Oligocene to the Late Miocene. We present in Fig. 10 a possible scenario depicting the evolution of the NCDS from the Eocene to $5 \mathrm{Ma}$. The evolution is drawn along a single section that would cross the present Mykonos core complex, but we projected the information gathered along the transect from Andros to Mykonos to describe the succession of events. Because of the lateral gradient of finite extension the evolution has stopped at various stages, first in Andros, then in Tinos and finally in Mykonos. The end of the evolution, that has brought the core complexes to their present altitude is not considered here. The absence of offshore data on the geometry and orientation of the steep normal faults separating the islands precludes to draw the final evolution in detail. These steep normal faults have only been represented in the final stage. 
An initial geometry is assessed $35 \mathrm{Ma}$ ago when the front of the Hellenic accretionary wedge reached the southern part of the Cyclades archipelago. $\mathrm{H} P-\mathrm{L} T$ metamorphic rocks have been formed and exhumed in the subduction channel. The base of the Cycladic Blueschists rest through a thrust on top of the Cycladic basement and its cover, lateral equivalent of the Gavrovo-Tripolitza Nappe. This thrust is visible on Ios island (Huet et al., 2009). At the roof of the Cycladic Blueschists the Vari Detachment separates them from the Upper Cycladic Nappe. This detachment has played an important role in the exhumation of the $\mathrm{H} P-\mathrm{L} T$ rocks during the Eocene. The Upper Cycladic Nappe is made of the Pelagonian continental basement and the overlying ophiolitic nappe; these two components are grouped under a single color in Fig. 10.

From 30 to $35 \mathrm{Ma}$, the African slab started to rollback and the stress regime turned to extensional in the Cyclades. The major thrust contacts were partly reactivated and controlled the localization of low-angle normal faults and extensional ductile shear zones. We have assumed that the most important lithological and structural discontinuity, the base of the Upper Cycladic Nappe, played the role of a major extensional detachment on which second order shallow-dipping extensional shear zones and faults root. This is based on the observation that the main detachments seen in the Cyclades are localized at the base of this nappe. The change of stress regime is accompanied by a displacement of the volcanic arc toward the South, due to slab retreat, and a relaxation of the disequilibrated thermal regime established during subduction and nappe stacking. This leads to a strong heating of the lower crust and some partial melting is occurs. Intrusive granites originate mostly from partial melting of the continental crust with little hybridization with juvenile magmas issued from the mantle although the source of heat is likely more basic magmas intruding the lower crust (Altherr and Siebel, 2002). The upper crust is boudinaged and the Cycladic Blueschists tend to fill the gap between the boudins. This leads to the formation of crustal-scale domes several tens of kilometers wide bounded by shallow-dipping ductile shear zones that evolve into normal faults when crossing the brittle-ductile transition. Detachments are here low-angle extensional systems made of a brittle part in the upper crust and a ductile part in the lower crust with a transition zone where cataclastic flow plays an important role like in the model of (Lister and Davis, 1989) and (Mehl et al., 2005).

One of these low-angle detachments is then selected and the deformation localizes afterward only along the NCDS. Asymmetric domes continue to form below the main detachment. During exhumation the domes reach the brittle-ductile transition and the low-angle ductile shear zones that continue their activity in the brittle field evolve progressively into low-angle normal faults. Andros and Tinos show approximately this stage, sealed by the intrusion of the granite at a depth of $7 \mathrm{~km}$. We have to assume here that the end of exhumation from $7 \mathrm{~km}$ to the surface has been achieved there by some other mechanism such as steep normal faults and/or erosion. The case of Mykonos shows a more evolved system where detachments can be active with a shallow dip quite close to the surface.

The first granite reaches the detachment and intrudes it. The main shear zone then migrates upward following the brittle-ductile transition uplifted by the intrusion. The granite and the base of the Upper Cycladic Nappe are deformed in the same continuum of extension and topto-the-northeast shearing. This is the stage reached in southeastern Tinos.

While a dome is forming in the lower crustal partially molten rocks the second granite intrudes the detachment further to the east and it shows the same behaviour. It intrudes the detachment and induces some ductile deformation in the basal part of the Upper Cycladic 
Nappe. It is itself intensely stretched and sheared below the detachment. A new shallowdipping normal fault forms higher in the structure that brings the syn-rift sediments into contact with a sliver of Upper Cycladic Unit sandwiched between the two detachments and locally in direct contact with the cataclastic granite. This is the stage visible in Mykonos.

\section{Discussion and conclusion}

We have shown in this paper that the North Cycladic detachments can be understood as various stages of evolution of a single crustal-scale structure, the North Cycladic Detachment System. We propose a scenario showing the progressive evolution of a single low-angle extensional structure, the NCDS and its interactions with two granitic intrusions. The observed transect from Andros to Mykonos, characterized by a gradient of finite extension, shows a single process that has reached different degrees of evolution along strike. It also shows structures fossilized at different depths, more ductile in the NW, more brittle in the SE.

As the proposed model is drawn along a single section to take advantage of this gradient and describe a progressive evolution of a detachment, it cannot take into account the probable non-cylindricity of the deformation. It is quite possible indeed that the end of the brittle deformation in Tinos is partly contemporaneous with the beginning of ductile deformation in the Mykonos granite for instance. The absence of detailed age data constraining the complete exhumation history on both islands precludes any further discussion on this question. The end of exhumation in the brittle field due to the Livada and Mykonos Detachments is however rather well constrained by fission-tracks data (Brichau et al., 2007) and the time ranges overlap. Nevertheless, the timing of exhumation related to the Tinos detachment still needs to be constrained by higher temperature methods such as ${ }^{39} \mathrm{Ar} /{ }^{40} \mathrm{Ar}$ on micas.

Other detachments and core complexes have been described in the Cyclades, among them the Naxos detachment that extends laterally on Paros island ([Buick, 1991b], [Gautier et al., 1993], [Vanderhaeghe, 2004] and [Duchêne et al., 2006]). This detachment is responsible for

the exhumation of the largest gneiss dome in the center of the Cyclades. An offset of $50 \mathrm{~km}$ was estimated between 16 and $8 \mathrm{Ma}$ (Brichau et al., 2006). The Upper Cycladic Unit is present above the detachment and the granite dated at 11-12 Ma ([Wijbrans and McDougall, 1988], [Keay et al., 2001] and [Koukouvelas and Kokkalas, 2003]) has intruded the gneiss dome. Molassic sediments are found on top of the edifice and they were deposited on the hanging wall extensional allochton (Kuhlemann et al., 2004). Their age ranges from the Early Miocene (they are the oldest Cenozoic sediments found in the Cyclades) to the Middle Miocene ([Angelier et al., 1978] and [Kuhlemann et al., 2004]). Is then the Naxos-Paros detachment, named the Naxos-Paros Extensional Fault System (Brichau et al., 2006), the southern extension of the Mykonos detachment or more generally of the NCDS? If one assumes a single detachment and a single large core complex interacting in a simple fashion, later disrupted by steep normal faults, one should expect a gradation of the age of sediments deposited on the northward moving hanging wall, with younger sediments in the south. We observed exactly the opposite, as sediments are older in Naxos than in Mykonos. We thus prefer to interpret the NCDS as a separate structure formed side by side with the Naxos detachment with geometric and dynamic relations that remain to be clarified.

An unsolved question is the amount of exhumation due to late steep faults. These faults are known to be present offshore most Aegean islands and some are recognized in the field like in Syros for instance. They thus played a role in the final exhumation after the NCDS had ceased 
its activity. Low-temperature thermochronology cannot really constrain the parts of exhumation respectively due to the detachment and to the steep normal faults. A thermochronological study further to the NW in the Olympos-Ossa-Pelion region (Lacassin et al., 2007) suggests that the steep normal faults that control the shape of the coastline there accelerated the exhumation from $\sim 4 \mathrm{Ma}$. If this is due, as claimed in the same study, to the migration of the North Anatolian Fault in the Aegean domain, one might expect to find similar ages in the Cyclades and then the part of exhumation due to the steep faults would be minor, but independent studies should be conducted to address this question.

One major point is the lateral extension of the NCDS. We have described it as a continuous structure, $130 \mathrm{~km}$ long, from the NW of Andros to Mykonos. This is thus a major structure that unlikely stops abruptly. Its eastward continuation toward Ikaria Island is quite obvious as similar features were described there ([Faure et al., 1991] and [Kumerics et al., 2005]). The deformation of the Cycladic Blueschists in southeast Evia is quite similar to what we have described on Andros with however a less intense shearing ([Gautier and Brun, 1994a] and [Jolivet et al., 1999]). It is then reasonable to extend the NCDS as far as the middle part of Evia? Further to the NW, especially in the Olympos-Ossa-Pelion region, no low-angle normal faults have been described and the major part of the Aegean extension is there brittle and related to steep normal faults ([Schermer, 1993] and [Lacassin et al., 2007]).

Radiochronology suggests a period of exhumation of $\mathrm{H} P-\mathrm{L} T$ rocks during the Eocene, like in

the Cyclades. Then, a period of slow vertical exhumation is recognized between $\sim 40$ and $20 \mathrm{Ma}$, afterwhich the last brittle-ductile increments between 20 and 15 Ma seem to be related to the steep faults that are still active today. This last period corresponds with little doubt to the Aegean extension. An offshore seismic study of this region has shown the existence of a shallow-dipping reflector interpreted by the authors as a low-angle normal fault that could be active in the recent period (Laigle et al., 2000). Its geometry and dip are reminiscent of the NCDS. It is thus possible that a still active portion of the NCDS exists as far as the offshore of Mt Olympos. This possibility poses the problem of the relation between this low-angle normal fault and the steep faults that can be observed onshore.

The NCDS and its possible extensions form a major extensional structure that was active during the formation of the Aegean Sea. All estimates of the amount of slip reach several tens of kilometers along a shallow-dipping shear zone. It separates the Cyclades archipelago and its $26 \mathrm{~km}$ thick crust from the northern Aegean domain where the crust is in average thinner and dissected by dextral strike-slip faults. A possible extension to the north-west is coeval with a steep topographic and crustal thickness gradient between continental Greece and the Aegean Sea.

In our scenario, the NCDS corresponds more or less to the reactivation of the Vardar ocean suture zone including the contact zone between the Pelagonian domain and the Cycladic Blueschists, and mechanically weaker lithologies. The distribution of extensional deformation thus seems to be largely controlled by the presence of a weak rheological level, i.e. the inherited thrust contact at the base of the Pelagonian. It has been shown by means of numerical (Le Pourhiet et al., 2004) and analogue modelling (Mattioni et al., 2006) that a shallow-dipping rheologically weak layer can be reactivated and that the fault pattern in the upper crust depends upon the rheological contrast with the host rocks in the footwall and hanging wall. In our model for the Aegean Sea the Vardar suture localizes extensional strain at crustal scale at the beginning of extension and all other second order extensional features root on this shear zone. After a while one detachment is selected and it localizes most of the 
extensional strain leading to the formation of core complexes. In this second stage the rheological contrast at the base of the Pelagonian is used as a preferred movement zone. This vision of strain localization in an extending crust significantly differs from previously published core complex models where the crust is supposed to be homogeneous thus giving much importance to the initial thermal (and rheological state) of the crust and lithosphere and to possible rheological changes during the course of extension such as partial melting ([Buck, 1991], [Chéry, 2001], [Rosenbaum et al., 2005] and [Vanderhaeghe and Teyssier, 2001]). The Aegean case is an example where inherited crustal-scale heterogeneities may have played a more important role in controlling extension than traditionnaly postulated. One of the characteristics of continental crust compared to oceanic crust is indeed its heterogeneity that should be considered as an important factor in strain localization.

The northern limit of the Cycladic plateau and its flat Moho would thus be controlled by a heritage of the Late Cretaceous to Eocene stage of subduction. The fact that the North Anatolian Fault and its satellites do not propagate in the crust south of the NCDS could also be controlled by the presence of different assemblage of crustal lithologies north and south of the NCDS.

An anisotropic mantle with an ancient frozen fabric can control initial localization of extensional structures (Vauchez et al., 1998) but in the case of the Aegean or other Mediterranean backarc basins it is likely that the mantle is weak and that its anisotropy is recent, contemporaneous with the Neogene extension (Jolivet et al., 2009). The main source of anisotropy could then reside in the mantle only at the very beginning of extension. The large-scale thrusts formed during the building of the Hellenides are more likely to have controlled the localization of the main extensional shear zones above the Aegean warm and probably weak mantle. This initial set up imposed strong lateral variations of the depth of the brittle-ductile transition, which allows to localize the extension and a dipping mechanical anisotropy of the crust, which allows an extensional structure to form and localize strain along low-angle shear zones for a long time period.

\section{Aknowledgments}

This paper is a contribution of the ANR EGEO Project. Special thanks are due to Bernard Grasemann and Olivier Vanderhaeghe who provided valuable comments on a first version of the paper.

\section{References}

Altherr and Siebel, 2002 R. Altherr and W. Siebel, I-type plutonism in a continental back-arc setting: Miocene granitoids and monzonites from the central Aegean Sea, Greece, Contrib. Mineral. Petrol. 143 (2002), pp. 397-415.

Altherr et al., 1979 R. Altherr, M. Schliestedt, M. Okrusch, E. Seidel, H. Kreuzer, W. Harre, H. Lenz, I. Wendt and G.A. Wagner, Geochronology of high-pressure rocks on Sifnos (Cyclades, Greece), Contrib. Mineral. Petrol. 70 (1979), pp. 245-255.

Altherr et al., 1982 R. Altherr, H. Kreuzer, I. Wendt, H. Lenz, G.A. Wagner, J. Keller, W. Harre and A. Hohndorf, A Late Oligocene/Early Miocene high temperature belt in the anticycladic crystalline complex (SE Pelagonian, Greece), Geol. Jahrb. 23 (1982), pp. 97-164. 
Angelier et al., 1978 J. Angelier, G. Glaçon and C. Muller, Sur la présence et la position tectonique du Miocène inférieur marin dans l'archipel de Naxos (Cyclades, Grèce), $C$. $R$. Acad. Sci., Paris 286 (1978), pp. 21-24.

Armijo et al., 1992 R. Armijo, H. Lyon-Caen and D. Papanikolaou, East-West extension and Holocene normal fault scarps in the Hellenic arc, Geology 20 (1992), pp. 491-494.

Armijo et al., 1996 R. Armijo, B. Meyer, G.C.P. King, A. Rigo and D. Papanastassiou, Quaternary evolution of the Corinth Rift and its implications for the Late Cenozoic evolution of the Aegean, Geophys. J. Int. 126 (1996), pp. 11-53

Armijo et al., 1999 R. Armijo, B. Meyer, A. Hubert and A. Barka, Westward propagation of the north Anatolian into the northern Aegean: timing and kinematics, Geology 27 (3) (1999), pp. 267-270.

Armijo et al., 2002 R. Armijo, B. Meyer, S. Navarro, G. King and A. Barka, Asymmetric slip partitionning in the Marmara Sea pull-apart: a clue to propagation processes of the North Anatolian Fault, Terra Nova 14 (2) (2002), pp. 80-84.

Aubourg et al., 2000 C. Aubourg, R. Hébert, L. Jolivet and G. Cartayrade, The magnetic fabric in a detachment shear zone: the example of Tinos island (Greece), Tectonophysics 321 (2000), pp. 219-236.

Avigad and Garfunkel, 1989 D. Avigad and Z. Garfunkel, Low-angle faults above and below a blueschist belt: Tinos Island, Cyclades, Greece, Terra Nova 1 (1989), pp. 182-187.

Avigad and Garfunkel, 1991 D. Avigad and Z. Garfunkel, Uplift and exhumation of highpressure metamorphic terranes: the example of the Cycladic blueschists belt (Aegean Sea), Tectonophysics 188 (1991), pp. 357-372.

Avigad et al., 1998 D. Avigad, G. Baer and A. Heimann, Block rotations and continental extension in the Central Aegean Sea: paleomagnetic and structural evidence from Tinos and Mykonos, Earth Planet. Sci. Lett. 157 (1998), pp. 23-40.

Blake et al., 1981 M.C. Blake, M. Bonneau, J. Geyssant, J.R. Kienast, C. Lepvrier, H. Maluski and D. Papanikolaou, A geological reconnaissance of the Cyclacic blueschist belt, Greece, Bull. Geol. Soc. Am. 92 (1981), pp. 247-254.

Bonneau, 1982 M. Bonneau, Evolution géodynamique de l'arc égéen depuis le Jurassique Supérieur jusqu'au Miocène, Bull. Soc. Géol. Fr. 7 (1982), pp. 229-242.

Bonneau, 1984 M. Bonneau, Correlation of the Hellenic nappes in the south-east Aegean and their tectonic reconstruction, in The Geological Evolution of the Eastern Mediterranean. In: J.E. Dixon and A.H.F. Robertson, Editors, Special Publication of the Geological Society of London, Blackwell Scientific Publications, Oxford (1984), pp. 517-527.

Bonneau and Kienast, 1982 M. Bonneau and J.R. Kienast, Subduction, collision et schistes bleus: exemple de l'Egée, Grèce, Bull. Soc. Géol. Fr. 7 (1982), pp. 785-791. 
Bonneau et al., 1980 M. Bonneau, J. Kienast, C. Lepvrier and H. Maluski, Tectonique et métamorphisme haute pression d'âge Eocène dans les Hellénides: exemple de l'île de Syros (Cyclades, Grèce), C. R. Acad. Sci., Paris 291 (1980), pp. 171-174.

Bozkurt and Sözbilir, 2004 E. Bozkurt and H. Sözbilir, Tectonic evolution of the Gediz Graben: field evidence for an episodic, two-stage extension in western Turkey, Geol. Mag. 141 (2004), pp. 63-79.

Brichau et al., 2006 S. Brichau, U. Ring, R.A. Ketcham, A. Carter, D. Stockli and M. Brunel, Constraining the long-term evolution of the slip rate for a major extensional fault system in the central Aegean, Greece, using thermochronology, Earth Planet. Sci. Lett. 241 (2006), pp. 293-306.

Brichau et al., 2007 S. Brichau, U. Ring, A. Carter, P. Monie, R. Bolhar, D. Stockli and M. Brunel, Extensional faulting on Tinos Island, Aegean Sea, Greece: how many detachments?, Tectonics 26 (2007), p. TC4009

Brichau et al., 2008 S. Brichau, U. Ring, A. Carter, R. Bolhar, P. Monié, D. Stockli and M. Brunel, Timing, slip rate, displacement and cooling history of the Mykonos detachment footwall, Cyclades, Greece, and implications for the opening of the Aegean Sea basin, $J$. Geol. Soc. London 165 (2008), pp. 263-277.

Brichau et al., 2009 Brichau, S., Thomson, S ., Ring, U., 2009. Thermochronometric constraints on the tectonic evolution of the Serifos detachment, Aegean Sea, Greece. Int J Earth Sci (Geol Rundsch), online version:

Bröcker, 1990 M. Bröcker, Blueschist-to-greenschist transition in metabasites from Tinos island, Cyclade, Greece: compositional control or fluid infiltration, Lithos 25 (1990), pp. 2539.

Bröcker and Enders, 1999 M. Bröcker and M. Enders, U-Pb zircon geochronology of unusual eclogite-facies rocks from Syros and Tinos (Cyclades, Greece), Geol. Mag. 136 (1999), pp. 111-118.

Bröcker and Franz, 1994 M. Bröcker and L. Franz, The contact aureole on Tinos (Cyclades, Greece). Part I: field relationships, petrography and P-T conditions, Chem. Erde 54 (1994), pp. 262-280.

Bröcker and Franz, 1998 M. Bröcker and L. Franz, Rb-Sr isotope studies on Tinos island (Cyclades, Greece): additional time constraints for metamorphism, extent of inflitrationcontrolled overprinting and deformational activity, Geol. Mag. 135 (1998), pp. 369-382.

Bröcker and Franz, 2000 M. Bröcker and L. Franz, The contact aureole on Tinos (Cyclades, Greece): tourmaline-biotite geothermometry and Rb-Sr geochronology, Mineral. Petrol. 70 (2000), pp. 257-283.

Bröcker and Pidgeon, 2007 M. Bröcker and R.T. Pidgeon, Protolith ages of meta-igneous and metatuffaceous rocks from the Cycladic Blueschist Unit, Greece: results of a Reconnaissance U-Pb Zircon Study, J. Geol. 115 (2007), pp. 83-98. 
Brunn et al., 1976 J.H. Brunn, I. Argyriadis, L.E. Ricou, A. Poisson, J. Marcoux and P.C. de Graciansky, Eléments majeurs de liaison entre Taurides et Hellénides, Bull. Soc. Géol. Fr. 18 (1976), pp. 481-497.

Buck, 1988 W.R. Buck, Flexural rotation of normal faults, Tectonics 7 (1988), pp. 959-973.

Buck, 1991 W.R. Buck, Modes of continental lithospheric extension, J. Geophys. Res. 96 (1991), pp. 20,161-20,178.

Buick, 1991a I.S. Buick, Mylonite fabric development on Naxos, Greece, J. Struct. Geol. 13 (1991), pp. 643-655

Buick, 1991b I.S. Buick, The late alpine evolution of an extensional shear zone, Naxos, Greece, J. Geol. Soc. 148 (1991), pp. 93-103

Buick and Holland, 1989 I.S. Buick and T.J.B. Holland, The P-T-t path associated with crustal extension, Naxos, Cyclades, Greece. In: J.S. Daly, Editor, Evolution of metamorphic belts, Geol. Soc. Spec. Pub (1989), pp. 365-369.

Burg et al., 1990 J.P. Burg, Z. Ivanov, L.E. Ricou, D. Dimor and L. Klain, Implications of shear sense criteria for the tectonic evolution of the Central Rhodope massif, southern Bulgaria, Geology 18 (1990), pp. 451-454.

Burg et al., 1995 J.P. Burg, I. Godfriaux and L.E. Ricou, Extension of the Mesozoic Rhodope thrust units in the Verstiskos-Kerdilion massifs (Northern Greece), C. R. Acad. Sci., Paris 320 (1995), pp. 889-896.

Burg et al., 1996 J.P. Burg, L.E. Ricou, Z. Ivanov, I. Godfriaux, D. Dimov and L. Klain, Synmetamorphic nappe complex in the Rhodope Massif. Structure and kinematics, Terra Nova 8 (1996), pp. 6-15

Chamot-Rooke et al., 2005 N. Chamot-Rooke, C. Rangin, X.L. Pichon and Dotmed working group, DOTMED: Deep Offshore Tectonics of the Mediterranean. A synthesis of deep marine data in eastern Mediterranean, Mém. Soc. Géol. Fr. 177 (2005) 64 pp.

Chéry, 2001 J. Chéry, Core complex mechanics: from the gulf of Corinth to the Snake Range, Geology 29 (2001), pp. 439-442.

Collettini et al., 2009 C. Collettini, C. Viti, S.A.F. Smith and R.E. Holdsworth, Development of interconnected talc networks and weakening of continental low-angle normal faults, Geology 37 (2009), pp. 567-570

Collins and Robertson, 1997 A.S. Collins and A.H.F. Robertson, Lycian melange, southwestern Turkey: an emplaced Late Cretaceous accretionary complex, Geology 25 (1997), pp. 255-258.

Collins and Robertson, 1999 A.S. Collins and A.H.F. Robertson, Evolution of the Lycian Allochthon, western Turkey, as a north- facing Late Palaeozoic to Mesozoic rift and passive continental margin, Geol. J. 34 (1999), pp. 107-138 
Coney and Harms, 1984 P.J. Coney and T.A. Harms, Cordilleran metamorphic core complexes, Cenozoic extensional relics of Mesozoic compression, Geology 12 (1984), pp. 550-554.

Creutzburg, 1977 Creutzburg, N., 1977. General geological map of Greece. Crete island. 1:200 000. Institute of Geological and Mining Research, Athens.

Crittenden et al., 1980 M.D. Crittenden, P.J. Coney and G.H. Davis, Cordilleran metamorphic core complexes, Geol. Soc. Amer., Mem. (1980), pp. 1-490.

Delvaux et al., 1995 D. Delvaux, R. Moeys, G. Stapel, A. Melnikov and V. Ermikov, Paleostress reconstructions and geodynamics of the Baikal region, Central Asia, Part I. Palaeozoic and Mesozoic pre-rift evolution, Tectonophysics 252 (1995), pp. 61-101.

Doutsos et al., 1993 T. Doutsos, G. Pe-Piper, K. Boronkay and I. Koukouvelas, Kinematics of the central Hellenides, Tectonics 12 (1993), pp. 936-953

Duchêne et al., 2006 S. Duchêne, R. Aïssa and O. Vanderhaeghe, Pressure-temperature-time evolution of metamorphic rocks from Naxos (Cyclades, Greece): constraints from Thermobarometry and Rb/Sr dating, Geodyn. Acta 19 (2006), pp. 299-319.

Eyidogan and Jackson, 1985 H. Eyidogan and J. Jackson, A seismological study of normal faulting in the Demirci, Alasehir and Gediz earthquakes of 1969-1970 in western Turkey: implications for the nature and geometry of deformation in the continental crust, Geophys. $J$. R. Astron. Soc. 81 (1985), pp. 569-607.

Famin et al., 2004 V. Famin, P. Philippot, L. Jolivet and P. Agard, Evolution of hydrothermal regime along a crustal shear zone, Tinos island, Greece, Tectonics 23 (2004)

Faure et al., 1991 M. Faure, M. Bonneau and J. Pons, Ductile deformation and syntectonic granite emplacement during the late Miocene extension of the Aegean (Greece), Bull. Soc. Géol. France 162 (1991), pp. 3-12.

Foster and Lister, 2009 M. Foster and G. Lister, Core-complex-related extension of the Aegean lithosphere initiated at the Eocene-Oligocene transition, J. Geophys. Res. 114 (2009), p. B02401

Gautier and Brun, 1994a P. Gautier and J.P. Brun, Crustal-scale geometry and kinematics of late-orogenic extension in the central Aegean (Cyclades and Evvia island), Tectonophysics 238 (1994), pp. 399-424.

Gautier and Brun, 1994b P. Gautier and J.P. Brun, Ductile crust exhumation and extensional detachments in the central Aegean (Cyclades and Evvia islands), Geodin. Acta 7 (1994), pp. 57-85.

Gautier et al., 1993 P. Gautier, J.P. Brun and L. Jolivet, Structure and kinematics of upper Cenozoic extensional detachement on Naxos and Paros (Cyclades Islands, Greece), Tectonics 12 (1993), pp. 1180-1194 
Grasemann and Petrakakis, 2007 Grasemann, B ., Petrakakis, K., 2007. Evolution of the Serifos Metamorphic Core Complex. In: G. Lister and M. Foster (Editors), Inside the Aegean Core Complexes. Journal of the Virtual Explorer, Electronic Edition.

Habert, 2004 Habert, G., 2004. Etude des relations entre la structure des granites et le contexte tectonique: exemple des contextes transpressifs, extensifs et sans tectonique. Thèse de Doctorat Thesis, Université de Toulouse III — Paul Sabatier, Toulouse, 326 pp.

Henjes-Kunst et al., 1988 F. Henjes-Kunst, R. Altherr, H. Kreuzer and B.T. Hansen, Disturbed U-Th-Pb systematics of young zircons and uranothites: the case of the Miocene Aegean granitoids (Greece), Chem. Geol. 73 (1988), pp. 125-145

Huet et al., 2009 B. Huet, L. Labrousse and L. Jolivet, Thrust or detachment? Exhumation processes in the Aegean: insight from a field study on Ios (Cyclades, Greece), Tectonics $\mathbf{2 8}$ (2009), p. TC3007

Iglseder et al., 2009 C. Iglseder, B. Grasemann, D.A. Schneider, K. Petrakakis, C. Miller, U.S. Klötzli, M. Thöni, A. Zámolyi and C. Rambouseka, I and S-type plutonism on Serifos (WCyclades, Greece), Tectonophysics 473 (2009), pp. 69-83

Jackson and McKenzie, 1984 J.A. Jackson and D. McKenzie, Active tectonics of the AlpineHimalayan belt between western Turkey and Pakistan, Geophys. J. R. Astron. Soc. 77 (1984), pp. 185-264

Jacobshagen et al., 1978 V. Jacobshagen, S. Dürr, F. Kockel, K.O. Kopp, G. Kowalczyk, H. Berckhemer and D. Büttner, Structure and geodynamic evolution of the Aegean region. In: H. Cloos, D. Roeder and K. Schmidt, Editors, Alps, Apennines, Hellenides, IUGG, Stuttgart (1978), pp. 537-564.

Jansen, 1973 Jansen, J.B.H., 1973. Geological map of Naxos (1/50 000). Nation. Inst. Geol. Mining Res., Athens.

Jarrige, 1992 J.J. Jarrige, Variation in extensional fault geometry related to heterogeneities within basement and sedimentary sequences, Tectonophysics 215 (1992), pp. 161-166.

Jolivet and Brun, in press Jolivet, L., Brun, J.P., in press. Cenozoic geodynamic evolution of the Aegean region. Int. J. Earth Sci. doi:10.1007/s00531-008-0366-4

Jolivet and Faccenna, 2000 L. Jolivet and C. Faccenna, Mediterranean extension and the Africa-Eurasia collision, Tectonics 19 (2000), pp. 1095-1106.

Jolivet et al., 1999 L. Jolivet and M. Patriat, Ductile extension and the formation of the Aegean Sea. In: B. Durand, L. Jolivet, F. Horvàth and M. Séranne, Editors, The Mediterranean Basins: Tertiary Extension within the Alpine Orogen. Geological Society Special Publication, Geological Society, London (1999), pp. 427-456.

Jolivet et al., 1994 L. Jolivet, J.P. Brun, P. Gautier, S. Lallemant and M. Patriat, 3-D kinematics of extension in the Aegean from the Early Miocene to the present, insight from the ductile crust, Bull. Soc. Géol. Fr. 165 (1994), pp. 195-209. 
Jolivet et al., 2004a L. Jolivet, G. Rimmelé, R. Oberhänsli, B. Goffé and O. Candan, Correlation of syn-orogenic tectonic and metamorphic events in the Cyclades, the Lycian Nappes and the Menderes massif, geodynamic implications, Bull. Soc. Geol. Fr. 175 (2004), pp. 217-238

Jolivet et al., 2004b L. Jolivet, V. Famin, C. Mehl, T. Parra, C. Aubourg, R. Hébert and P. Philippot, Progressive strain localisation, boudinage and extensional metamorphic complexes, the Aegean Sea case. In: D.L. Whitney, C. Teyssier and C.S. Siddoway, Editors, Gneiss Domes in Orogeny, Geological Society of America Special Paper vol. 380, Geological Society of America, Boulder, Colorado (2004), pp. 185-210.

Jolivet et al., 2009 L. Jolivet, C. Faccenna and C. Piromallo, From Mantle to crust: stretching the Mediterranean, Earth Planet. Sci. lett. 285 (2009), pp. 198-209

10.1016/j.epsl.2009.06.017.

Karagianni et al., 2005 E.E. Karagianni, C.B. Papazachos, D.G. Panagiotopoulos, P. Suhadolc, A. Vuan and G.F. Panza, Shear velocity structure in the Aegean area obtained by inversion of Rayleigh waves, Geophys. J. Int. 160 (2005), pp. 127-143

Katzir et al., 1996 Y. Katzir, A. Matthews, Z. Garfunkel, M. Schliestedt and D. Avigad, The tectono-metamorphic evolution of a dismembered ophiolite (Tinos, Cyclades, Greece), Geol. Mag. 133 (1996), pp. 237-254.

Keay et al., 2001 S. Keay, G. Lister and I. Buick, The timing of partial melting, Barrovian metamorphism and granite intrusion in the Naxos metamorphic core complex, Cyclades, Aegean Sea, Greece, Tectonophysics 342 (2001), pp. 275-312.

Keiter et al., 2004 M. Keiter, K. Piepjohn, C. Ballhaus, M. Lagos and M. Bode, Structural development of high-pressure metamorphic rocks on Syros island (Cyclades, Greece), $J$. Struct. Geol. 26 (2004), pp. 1433-1445

Koukouvelas and Aydin, 2002 I.K. Koukouvelas and A. Aydin, fault structure and related basins of the North Aegean Sea and its surroundings, Tectonics 21 (2002), p. 1046 10.1029/2001TC901037.

Koukouvelas and Kokkalas, 2003 I.K. Koukouvelas and S. Kokkalas, Emplacement of the Miocene west Naxos pluton (Aegean Sea, Geece): a structural study, Geol. Mag. 140 (2003), pp. 45-61.

Kuhlemann et al., 2004 J. Kuhlemann, W. Frisch, I. Dunkl, M. Kázmér and G. Schmiedl, Miocene siliciclastic deposits of Naxos Island: geodynamic and environmental implications for the evolution of the southern Aegean Sea (Greece). In: M. Bernet and C. Spiegel, Editors, Detrital Thermochronology - Provenance Analysis, Exhumation, and Landscape Evolution of Mountain Belts: Geological Society of America, Special Paper, Geological Society of America (2004), pp. 51-65.

Kumerics et al., 2005 C. Kumerics, U. Ring, S. Brichau, J. Glodny and P. Monié, The extensional Messaria shear zone and associated brittle detachment faults, Aegean Sea, Greece, J. Geol. Soc. 162 (2005), pp. 701-721. 
Lacassin et al., 2007 Lacassin, R., Arnaud, N., Leloup, P.H., Armijo, R ., Meyer, B., 2007. Exhumation of metamorphic rocks in $\mathrm{N}$ Aegean: the path from shortening toextension and extrusion. eEarth Discuss., 2: 1-35.

Laigle et al., 2000 M. Laigle, A. Hirn, M. Sachpazi and N. Roussos, North Aegean crustal deformation: an active fault imaged to $10 \mathrm{~km}$ depth by reflection seismic data, Geology $\mathbf{2 8}$ (2000), pp. 71-74

Le Pichon and Angelier, 1979 X. Le Pichon and J. Angelier, The Hellenic arc and trench system: a key to the neotectonic evolution of the eastern Mediterranean area, Tectonophysics 60 (1979), pp. 1-42.

Le Pichon and Angelier, 1981 X. Le Pichon and J. Angelier, The Aegean Sea, Philos. Trans. R. Soc. Lond. 300 (1981), pp. 357-372.

Le Pourhiet et al., 2004 L. Le Pourhiet, E. Burov and I. Moretti, Rifting through a stack of inhomogeneous thrusts (the dipping pie concept), Tectonics 23 (TC4005) (2004) 10.1029/2003TC001584

Le Pourhiet et al., 2006 L. Le Pourhiet, L. Mattioni and I. Moretti, 3D modelling of rifting through a pre-existing stack of nappes in the Gulf of Corinth (Greece) a mixed analogue/numerical approach. In: S.J.H. Buiter and G. Schreurs, Editors, Analogue and Numerical Modelling of Crustal-scale Processes. Special Publications, Geological Society, London (2006), pp. 233-252.

Lee and Lister, 1992 J. Lee and G.S. Lister, Late Miocene ductile extension and detachment faulting, Mykonos, Greece, Geology 20 (1992), pp. 121-124.

Lister and Davis, 1989 G.S. Lister and G.A. Davis, The origin of metamorphic core complexes and detachment faults formed during Tertiary continental extension in the northern Colorado River region, U.S.A, J. Struct. Geol. 11 (1989), pp. 65-94.

Lister et al., 1984 G.S. Lister, G. Banga and A. Feenstra, Metamorphic core complexes of cordilleran type in the Cyclades, Aegean Sea, Greece, Geology 12 (1984), pp. 221-225.

Lucas, 1999 I. Lucas, Le pluton de Mykonos-Delos-Rhenee (Cyclades, Grèce): un exemple de mise en place synchrone de l'extension crustale, Université d'orléans, Orléans (1999) $491 \mathrm{pp}$.

Lyon-Caen et al., 1988 H. Lyon-Caen, R. Armijo, J. Drakopoulos, J. Baskoutass, N. Delibassis, R. Gaulon, V. Kouskouna, K. Latoussakis, K. Makropoulos, P. Papadimitriou, D. Papanastassiou and G. Pedotti, The 1986 Kalamata (South Peloponnesus) earthquake: detailed study of a normal fault, evidences for E-W extension in the Hellenic Arc, J. Geophys. Res. 93 (1988), pp. 14967-15000.

Maluski et al., 1987 H. Maluski, M. Bonneau and J.R. Kienast, Dating the metamorphic events in the Cycladic area: ${ }^{39} \mathrm{Ar} /{ }^{40} \mathrm{Ar}$ data from metamorphic rocks of the island of Syros (Greece), Bull. Soc. Géol. Fr. 8 (1987), pp. 833-842. 
Martin et al., 2006 L. Martin, S. Duchêne, E. Deloule and O. Vanderhaeghe, The isotopic composition of zircon and garnet: a record of the metamorphic history of Naxos, Greece, Lithos 87 (2006), pp. 174-192.

Mattioni et al., 2006 L. Mattioni, L. Le Pourhiet and I. Moretti, Rifting through a heterogeneous crust: insights from analogue models and application to the Gulf of Corinth. In: S.J.H. Buiter and G. Schreurs, Editors, Analogue and Numerical Modelling of Crustal-scale Processes, Geological Society, London (2006), pp. 213-231.

Mehl et al., 2005 C. Mehl, L. Jolivet and O. Lacombe, From ductile to brittle: evolution and localization of deformation below a crustal detachment (Tinos, Cyclades, Greece), Tectonics 24 (2005), p. TC4017 10.1029/2004TC001767.

Mehl et al., 2007 C. Mehl, L. Jolivet, O. Lacombe, L. Labrousse and G. Rimmelé, Structural evolution of Andros island (Cyclades, Greece): a key to the behaviour of a flat detachment within an extending continental crust. In: T. Taymaz, Y. Dilek and Y. Ylmaz, Editors, The Geodynamics of the Aegean and Anatolia. Special Publications, Geological Society, London (2007), pp. 41-73 10.1144/SP291.3 0305-8719/07/\$15.00

Melidonis, 1980 M.G. Melidonis, The geology of Greece: the geological structure and mineral deposits of Tinos island (Cyclades, Greece), Inst. Geol. Min. Expl., Athens 13 (1980), pp. 1-80.

Melosh, 1990 H.J. Melosh, Mechanical basis for low-angle normal faulting in the Basin and Range province, Nature 343 (1990), pp. 331-335.

Morris and Anderson, 1996 A. Morris and A. Anderson, First paleaomagnetic results from the Cycladic Massif, Greece, and their implications for Miocene extension directions and tectonic models in the Aegean, Earth Planet. Sci. Lett. 142 (1996), pp. 397-408.

Okay and Satir, 2000 A.I. Okay and M. Satir, Coeval plutonism and magmatism in a latest Oligocene metamorphic core complex in Northwest Turkey, Geol. Mag. 137 (2000), pp. 495516.

Okay and Tüysüz, 1999 A. Okay and O. Tüysüz, Tethyan sutures of northern Turkey. In: B. Durand, L. Jolivet, F. Horvath and M. Séranne, Editors, The Mediterranean Basins: Tertiary Extension within the Alpine Orogen. Special Publications, Geological Society, London (1999), pp. 475-515.

Papanikolaou, 1977 D.J. Papanikolaou, Contribution to the geology of the Aegean Sea: the island of Andros, Ann. Geol. Pays Hell. 29 (1977), pp. 477-553.

Papanikolaou, 1987 D. Papanikolaou, Tectonic evolution of the Cycladic blueschist belt (Aegean Sea, Greece). In: H.C. Helgeson, Editor, Chemical Transport in Metasomatic Processes, D. Reidel Publishing Company, Dordrecht (1987), pp. 429-450.

Papanikolaou et al., 2004 D. Papanikolaou, H. Barghathi, C. Dabovski, R. Dimitriu, A. ElHawat, D. Ioane, H. Kranis, A. Obeidi, C. Oaie, A. Seghedi and I. Zagorchev, TRANSMED Transect VII: East European Craton-Scythian Platform-Dobrogea-Balkanides - Rhodope Massif - Hellenides - East Mediterranean- Cyrenaica. In: W. Cavazza, F.M. Roure, W. 
Spakman, G.M. Stampfli and P.A.Z., Editors, The TRANSMED Atlas - the Mediterranean Region from Crust to Mantle, Springer, Berlin, Heidelberg (2004).

Parra et al., 2002 T. Parra, O. Vidal and L. Jolivet, Relation between deformation and retrogression in blueschist metapelites of Tinos island (Greece) evidenced by chlorite-mica local equilibria, Lithos 63 (2002), pp. 41-66

Patel et al., 1993 Patel, R.C., Singh, S., Asokan, A., Manickavasagam, R.M ., Jain, A.K.M., 1993. Extensional tectonics in the Himalayan orogen, Zanskar, NW India. In: P.J. Treloar and M.P. Searle (Editors), Himalayan Tectonics. Geological Society, London, London, pp. 445460 doi:10.1144/GSL.SP.1993.074.01.30

Patriat and Jolivet, 1998 M. Patriat and L. Jolivet, Post-orogenic extension and shallowdipping shear zones, study of a brecciated decollement horizon in Tinos (Cyclades, Greece), C. R. Acad. Sci. Paris 326 (1998), pp. 355-362.

Patzak et al., 1994 M. Patzak, M. Okrusch and H. Kreuzer, The Akrotiri unit on the island of Tinos, Cyclades, Greece: witness of a lost terrane of Late Cretaceous age, $\mathrm{N}$. Jb. Geol. Paläont. Abh. 194 (1994), pp. 211-252.

Petit and Deverchère, 2006 C. Petit and J. Deverchère, Structure and evolution of the Baikal rift: a synthesis, Geochem. Geophys. Geosyst. 7 (2006), p. Q11016 10.1029/2006GC001265

Piqué and Laville, 1996 A. Piqué and E. Laville, The Central Atlantic rifting: reactivation of Palaeozoic structures?, J. Geodyn. 21 (1996), pp. 235-255.

Ramsay and Huber, 1987 J.G. Ramsay and M.I. Huber, Techniques of Modern Structural Geology — Strain Analysis, Academic Press, London (1987).

Reinecke et al., 1982 T. Reinecke, R. Altherr, B. Hartung, K. Hatzipanagiotou, H. Kreuzer, W. Harre, H. Klein, J. Keller, E. Geenen and H. Böger, Remnants of a late Cretaceous high temperature bet on the island of Anafi (Cyclades, Greece), N. Jb. Miner. Abh 145 (1982), pp. 157-182.

Ring and Layer, 2003 U. Ring and P.W. Layer, High-pressure metamorphism in the Aegean, eastern Mediterranean: underplating and exhumation from the Late Cretaceous until the Miocene to Recent above the retreating Hellenic subduction zone, Tectonics 22 (2003) 10.1029/2001TC001350.

Stolz et al., 1997 J. Stolz, M. Engi and M. Rickli, Tectonometamorphic evolution of SE Tinos, Cyclades, Greece. Schweiz, Mineral. Petrogr. Mitt. 77 (1997), pp. 209-231.

Ring et al., 2001 U. Ring, P.W. Layer and T. Reischmann, Miocene high-pressure metamorphism in the Cyclades and Crete, Aegean Sea, Greece: evidence for large-magnitude displacement on the Cretan detachment, Geology 29 (2001), pp. 395-398.

Ring et al., 2003 U. Ring, S.N. Thomson and M. Bröcker, Fast extension but little exhumation: the Vari detachment in the Cyclades, Greece, Geol. Mag. 140 (2003), pp. 245252. 
Ring et al., 2007a U. Ring, J. Glodny, T. Will and S. Thomson, An Oligocene extrusion wedge of blueschists-facies nappes on Evia, Aegean Sea, Greece: implications for the early exhumation of high-pressure rocks, J. Geol. Soc. London 164 (2007), pp. 637-652.

Ring et al., 2007b U. Ring, T. Will, J. Glodny, C. Kumerics, K. Gessner, S. Thomson, T. Güngör, P. Monie, M. Okrusch and K. Drüppel, Early exhumation of high-pressure rocks in extrusion wedges: cycladic blueschist unit in the eastern Aegean, Greece, and Turkey, Tectonics 26 (2007), p. TC2001 10.1029/2005TC001872.

Rollet et al., 2002 N. Rollet, J. Déverchère, M.O. Beslier, P. Guennoc, J.P. Réhault, M. Sosson and C. Truffert, Back -arc extension, tectonic inheritance and volcanism in the Ligurian Sea, western Mediterranean, Tectonics 21 (2002) 10.1029.

Rosenbaum et al., 2005 G. Rosenbaum, K. Regenauer-Lieb and R. Weinberg, Continental extension: from core complexes to rigid block faulting, Geology 33 (7) (2005), pp. 609-612 10.1130/G21477.1.

Sanchez-Gomez et al., 2002 M. Sanchez-Gomez, D. Avigad and A. Heiman, Geochronology of clasts in allochthonous Miocene sedimentary sequences on Mykonos and Paros islands: implications for back - arc extension in the Aegean Sea, J. Geol. Soc. London 159 (2002), pp. 45-60.

Schermer, 1993 E.R. Schermer, Geometry and kinematics of continental basement deformation during the Alpine orogeny, Mt. Olympos region, Greece, J. Struct. Geol. 15 (1993), pp. 571-591.

Skarpelis, 2002 N. Skarpelis, Geodynamics and evolution of the Miocene mineralization in the Cycladic-Pelagonian Belt, Hellenides, Bull. Geol. Soc. Greece XXXIV/6 (2002), pp. 2191-2206.

Sotiropoulos et al., 2003 S. Sotiropoulos, E. Kamberis, M.V. Triantaphyllou and T. Doutsos, Thrust sequences in the central part of the External Hellenides, Geol. Mag. 140 (2003), pp. 661-668.

Taymaz et al., 1991 T. Taymaz, J. Jackson and D. McKenzie, Active tectonics of the north and central Aegean Sea, Geophys. J. Int. 106 (1991), pp. 433-490.

Tirel et al., 2004a C. Tirel, J.P. Brun and E. Burov, Thermo-mechanical modeling of extensional gneiss domes. In: D.L. Whitney, C. Teyssier and C.S. Siddoway, Editors, Gneiss Domes in Orogeny, Geological Society of America Special Paper, Boulder, Colorado (2004), pp. 67-78.

Tirel et al., 2004b C. Tirel, F. Gueydan, C. Tiberi and J.P. Brun, Aegean crustal thickness inferred from gravity inversion. Geodynamical implications, Earth Planet. Sci. Lett. 228 (2004), pp. 267-280.

Trotet et al., 2001a F. Trotet, L. Jolivet and O. Vidal, Tectono-metamorphic evolution of Syros and Sifnos islands (Cyclades, Greece), Tectonophysics 338 (2001), pp. 179-206. 
Trotet et al., 2001b F. Trotet, O. Vidal and L. Jolivet, Exhumation of Syros and Sifnos metamorphic rocks (Cyclades, Greece). New constraints on the P-T paths, Eur. J. Mineral. 13 (2001), pp. 901-920.

Tzankov et al., 1996 T. Tzankov, D. Angelova, R. Nakov, B.C. Burchfiel and L.H. Royden, The Sub-Balkan graben system of central Bulgaria, Basin Res. 8 (1996), pp. 125-142.

Vandenberg and Lister, 1996 L.C. Vandenberg and G.S. Lister, Structural analysis of basement tectonics from the Aegean metamorphic core complex of Ios, Cyclades, Greece, $J$. Struct. Geol. 18 (1996), pp. 1437-1454.

Vanderhaeghe, 2004 O. Vanderhaeghe, Structural development of the Naxos migmatite dome. In: D.L. Whitney, C. Teyssier and C.S. Siddoway, Editors, Gneiss Domes in Orogeny, Geological Society of America, Boulder, Colorado (2004), pp. 211-227.

Vanderhaeghe et al., 2007 Vanderhaeghe, O., Hibsch, C., Siebenaller, L., Duchêne, S., Kruckenberg, S., Fotiadis, A., Martin, L ., de Saint Blanquat, M., 2007. Penrose conference — extending a continent — Naxos Field guide. Journal of the Virtual Explorer, 28: Paper 4.

Vanderhaeghe and Teyssier, 2001 O. Vanderhaeghe and C. Teyssier, Crustal-scale rheological transitions during late-orogenic collapse, Tectonophysics 335 (2001), pp. 211228.

Vauchez et al., 1998 A. Vauchez, A. Tommasi and G. Barruol, Rheological heterogeneity, mechanical anisotropy and deformation of the continental lithosphere, Tectonophysics 296 (1998), pp. 61-86.

Vigner, 2002 Vigner, A., 2002. Images sismiques par réflexions verticales et grand-angle de la croûte en contexte extensif: les Cyclades et le Fossé Nord-Egéen. Thèse de doctorat Thesis, Institut de Physique du Globe, Paris, 269 pp.

Wernicke, 1981 B. Wernicke, Low-angle normal faults in the Basin and Range province: nappe tectonics in an extending orogen, Nature 291 (1981), pp. 645-648.

Wernicke, 1995 B. Wernicke, Low-angle normal faults and seismicity: a review, J. Geophys. Res. 100 (1995), pp. 20159-20174.

Wernicke et al., 2008 B. Wernicke, J.L. Davis, N.A. Niemi, P. Luffi and S. Bisnath, Active megadetachment beneath the western United States, J. Geophys. Res. 113 (2008), p. B11409 10.1029/2007JB005375

Wijbrans and McDougall, 1986 J.R. Wijbrans and I. McDougall, ${ }^{40} \mathrm{Ar} /{ }^{39} \mathrm{Ar}$ dating of white micas from an alpine high-pressure metamorphic belt on Naxos (Greece); the resetting of the argon isotopic system, Contrib. Mineral. Petrol. 93 (1986), pp. 187-194

Wijbrans and McDougall, 1988 J.R. Wijbrans and I. McDougall, Metamorphic evolution of the Attic Cycladic Metamorphic Belt on Naxos (Cyclades, Greece) utilizing ${ }^{40} \mathrm{Ar} /{ }^{39} \mathrm{Ar}$ age spectrum measurements, J. Metamorph. Geol. 6 (1988), pp. 571-594. 
Zeffren et al., 2005 S. Zeffren, D. Avigad, A. Heimann and Z. Gvirtzman, Age resetting of hanging wall rocks above a Tertiary low-angle detachment, Tinos island, Aegean Sea, Tectonophysics 400 (2005), pp. 1-25

Zorin, 1999 Y.A. Zorin, Geodynamics of the western part of the Mongolia-Okhotsk collisional belt, Trans-Baikal region (Russia) and Mongolia, Tectonophysics 306 (1999), pp. 33-56. 


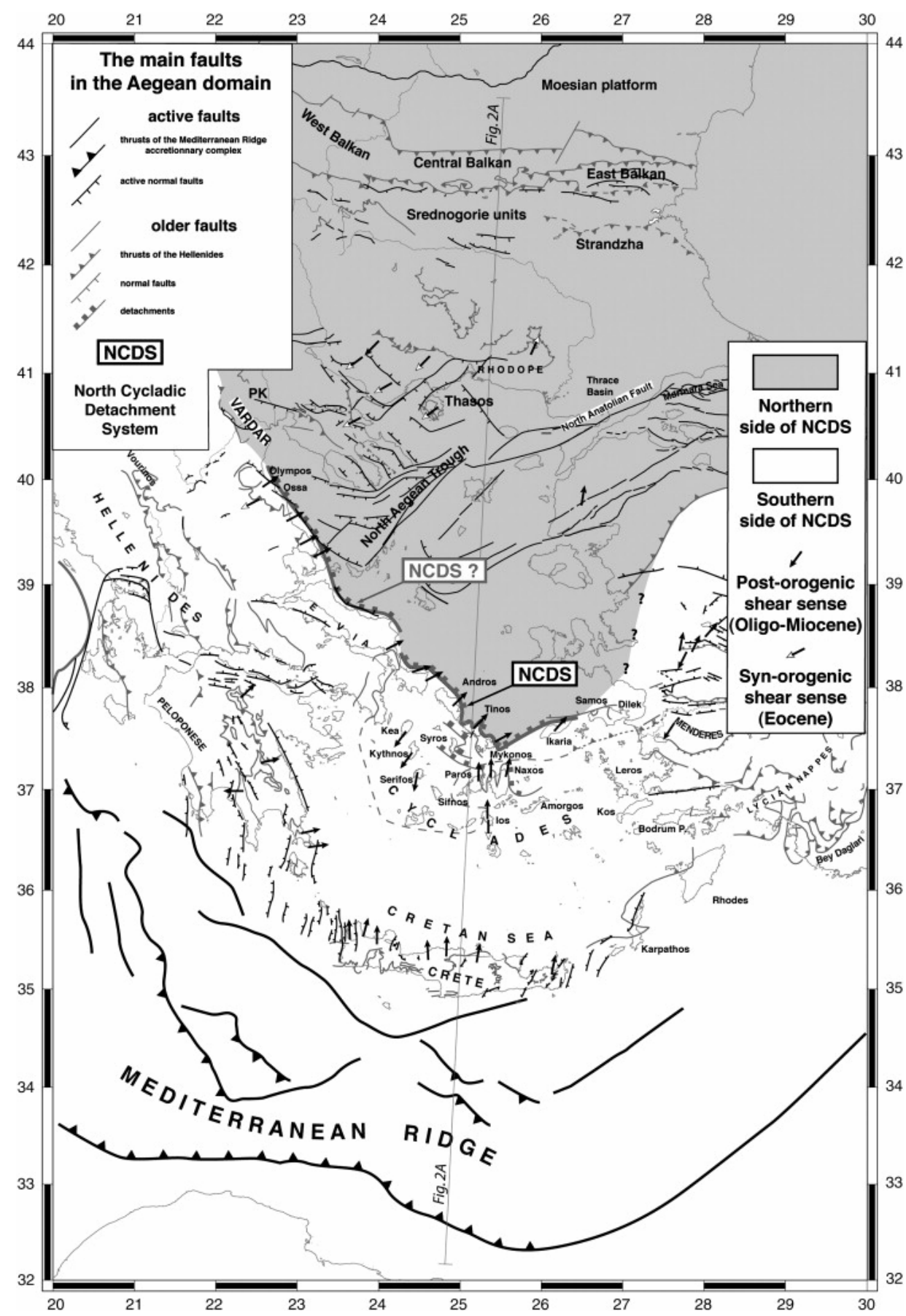

Fig. 1. Tectonic map of the Aegean region showing the main active faults and the main thrusts and Oligo-Miocene detachments in the Cyclades ([Creutzburg, 1977], [Bonneau, 1982], [Lyon-Caen et al., 1988], [Burg et al., 1990], [Burg et al., 1995], [Burg et al., 1996], [Armijo et al., 1992], [Armijo et al., 1999], [Tzankov et al., 1996], [Collins and Robertson, 1997], [Collins and Robertson, 1999], [Okay and Tüysüz, 1999], [Okay and Satir, 2000], [Koukouvelas and Aydin, 2002], [Jolivet et al., 2004a], [Jolivet et al., 2004b], [Papanikolaou et al., 2004], [Chamot-Rooke et al., 2005] and [Iglseder et al., 2009]). NCDS: North Cycladic Detachment System (in grey a possible north-eastward extension of the NCDS). Small arrows represent the average direction of Oligo-Miocene stretching lineations in the main metamorphic complexes. 

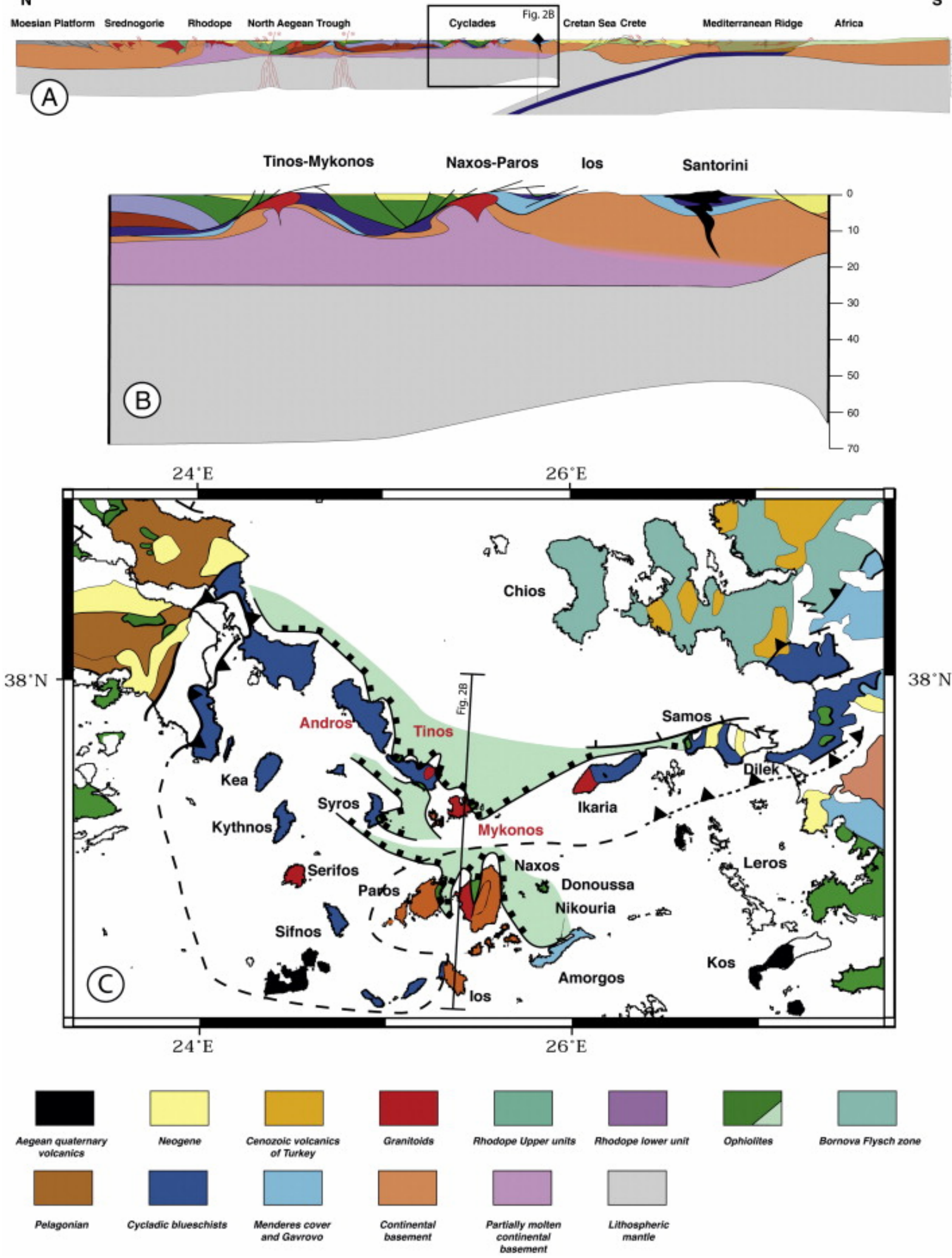

Fig. 2. The geological context of the NCDS. A: N-S cross-section of the Aegean region from the African margin the Balkans (Jolivet and Brun, in press). B: detail of the same crosssection centered on the Cyclades archipelago. C: schematic geological map of the Cyclades showing the Upper Cycladic Nappe and its lateral equivalent onland as ophiolitic massifs. The Upper Cycladic Nappe has been extended offshore above the main detachments to show its extension before the formation of the Aegean Sea. 
(A)

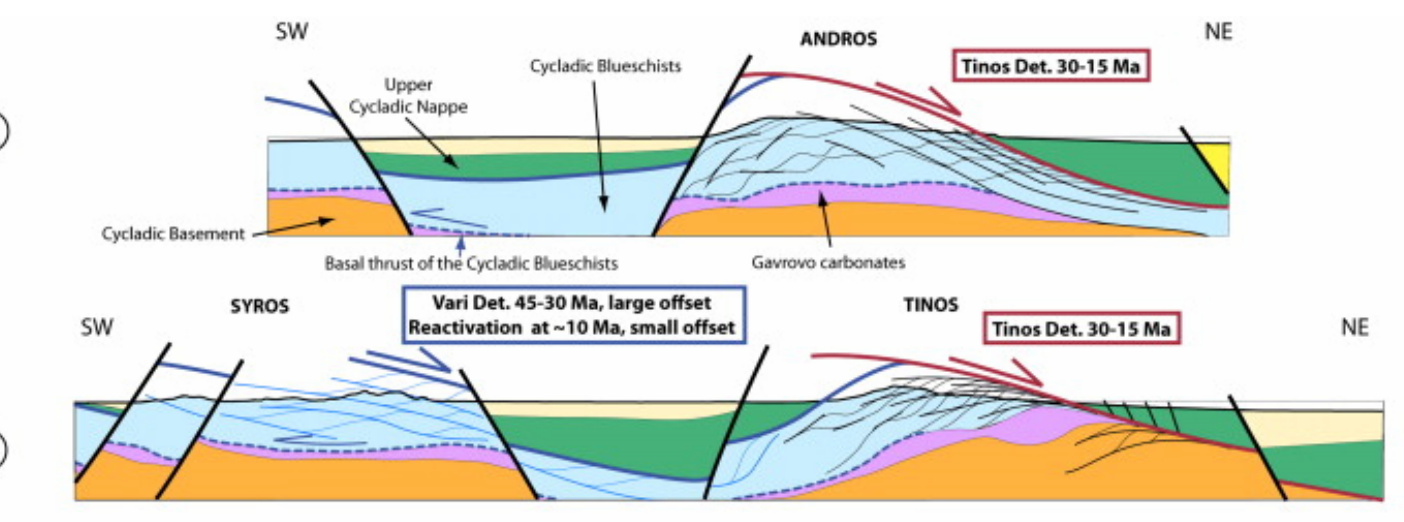

(B)
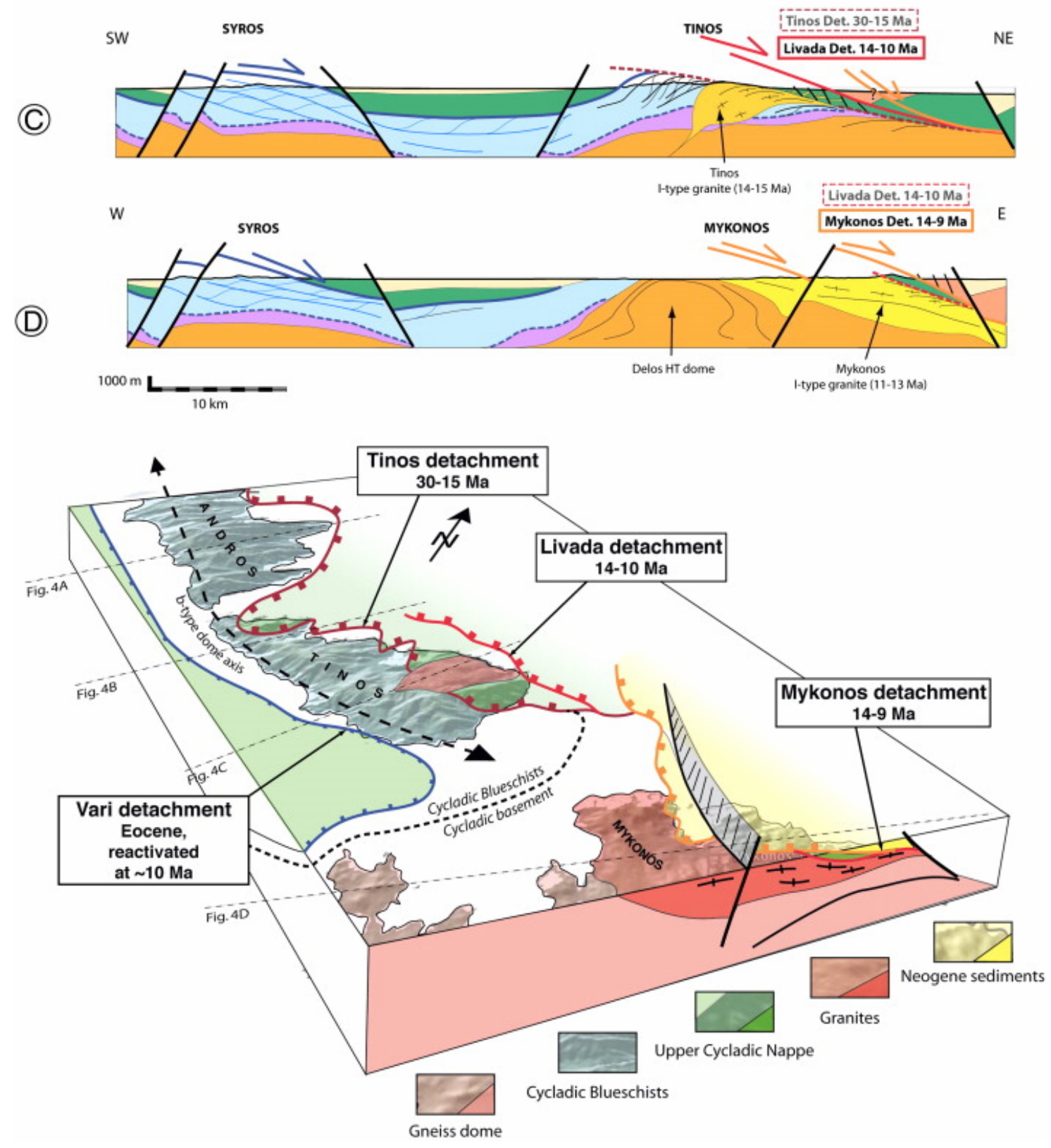

Fig. 3. Upper: Geological sections across the Andros, Tinos, Mykonos and Syros showing the main tectonic units and the main detachments, their geometrical relations and respective timing. Lower: 3D view of the northern Cyclades showing the geometrical relations between the Tinos, Livada and Mykonos detachments. 


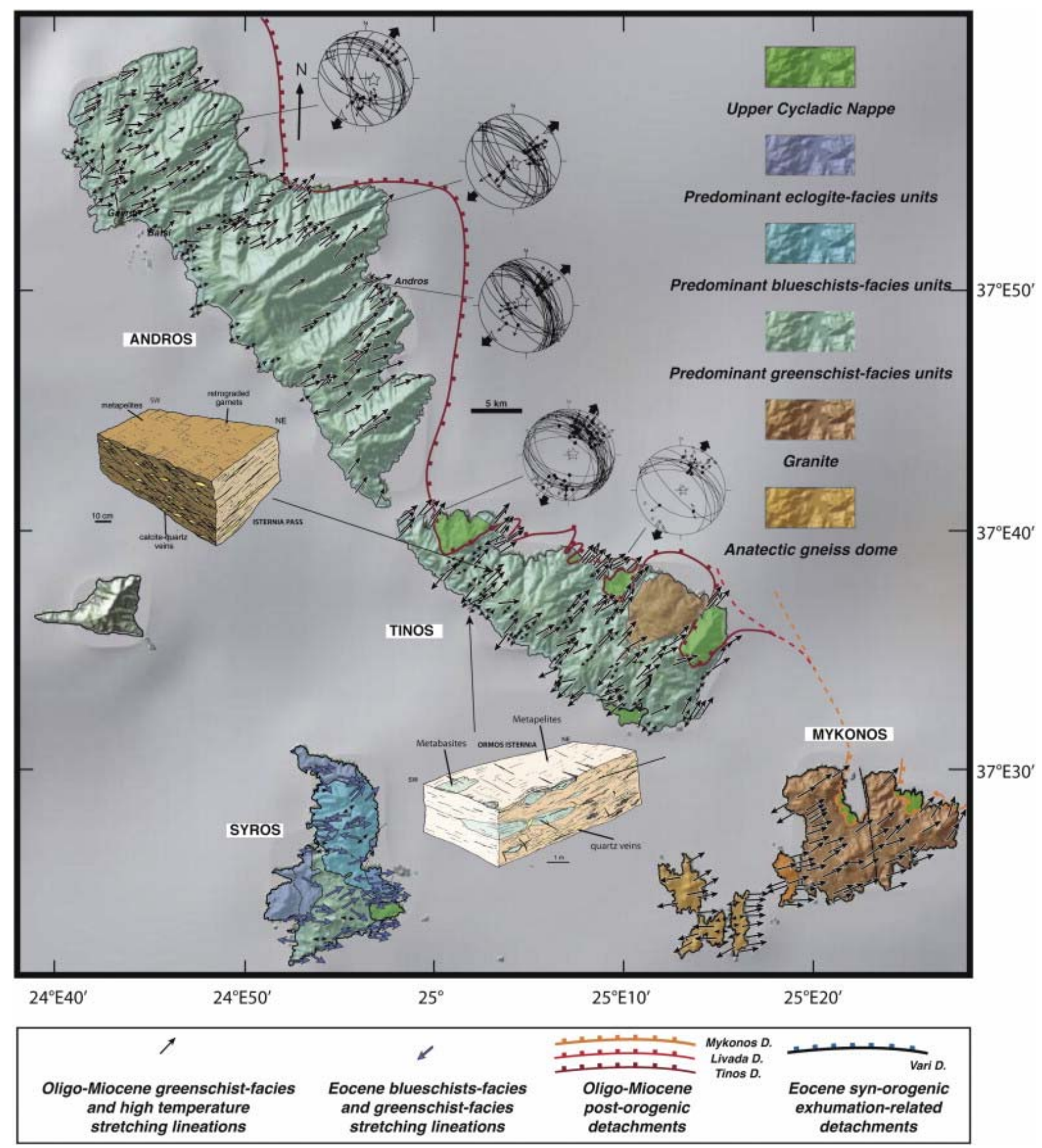

Fig. 4. Tectonic map of Syros, Andros, Tinos and Mykonos Islands showing the main lithological units, the detachments, the Oligo-Miocene and Eocene stretching lineations ([Faure et al., 1991], [Gautier and Brun, 1994a], [Gautier and Brun, 1994b], [Jolivet et al., 1999], [Lucas, 1999], [Trotet et al., 2001a], [Mehl et al., 2005] and [Mehl et al., 2007]) and examples of stereograms illustrating the geometry and kinematics of minor normal faults. 3D block-diagrams: two examples of footwall deformation on Tinos; asymmetrical highly sheared metapelites near Isternia and symmetrical boudinage, conjugate minor shear zones and crenulation cleavage at Ormos Isternia. 

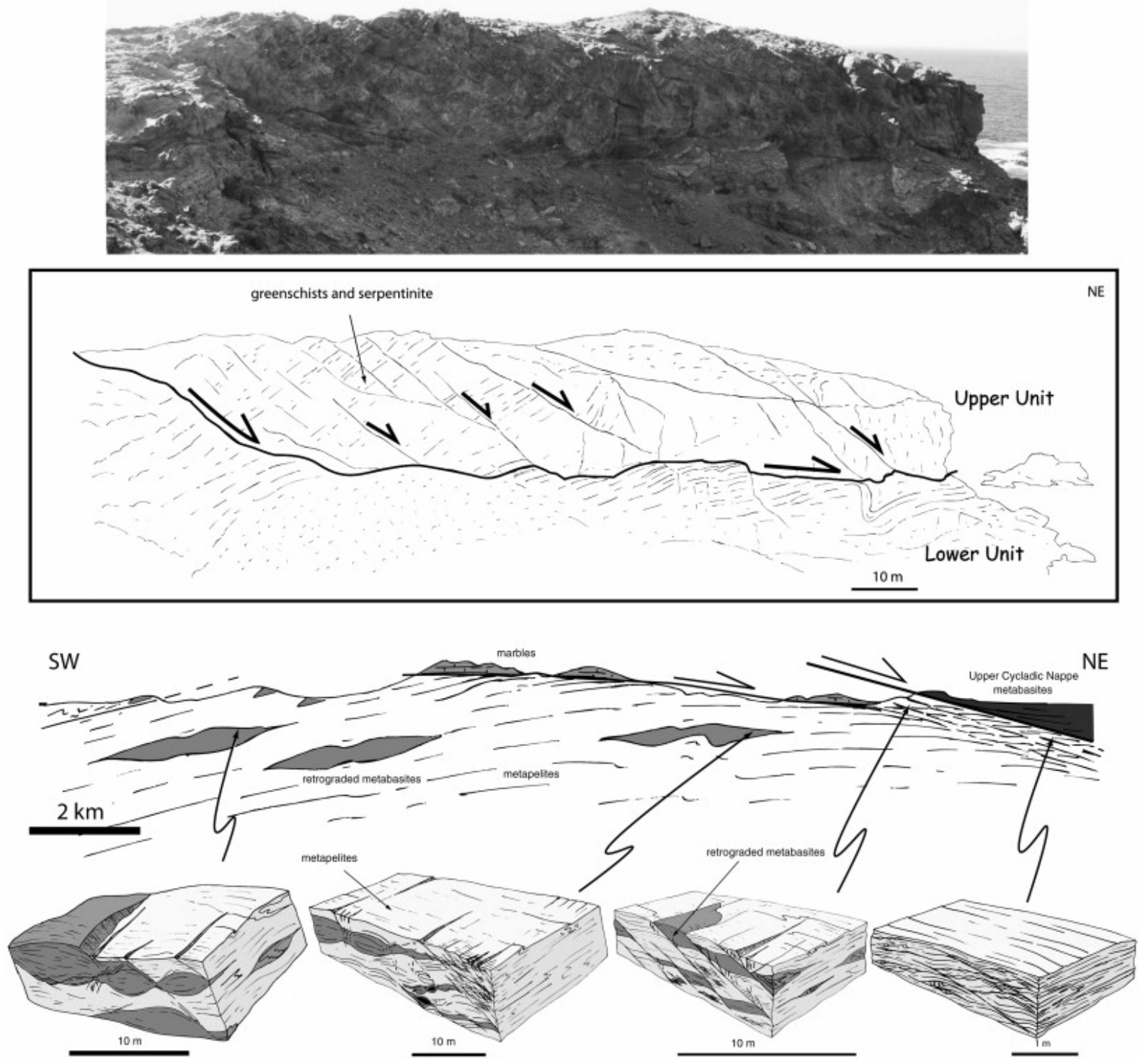

Fig. 5. The Tinos Detachment on Andros. Upper: photograph of the detachment near the Semiramis wrecked boat and an interpretation. The detachment separates greenschists and serpentinite in the hanging wall from micaschists and cataclasites in the footwall. A series of NE-dipping normal faults root in the detachment. Lower: evolution of the footwall deformation along a SW-NE cross-section parallel to the stretching direction. The shape of boudins evolves from symmetrical to asymmetrical and the density of shear bands increases toward the detachment. 

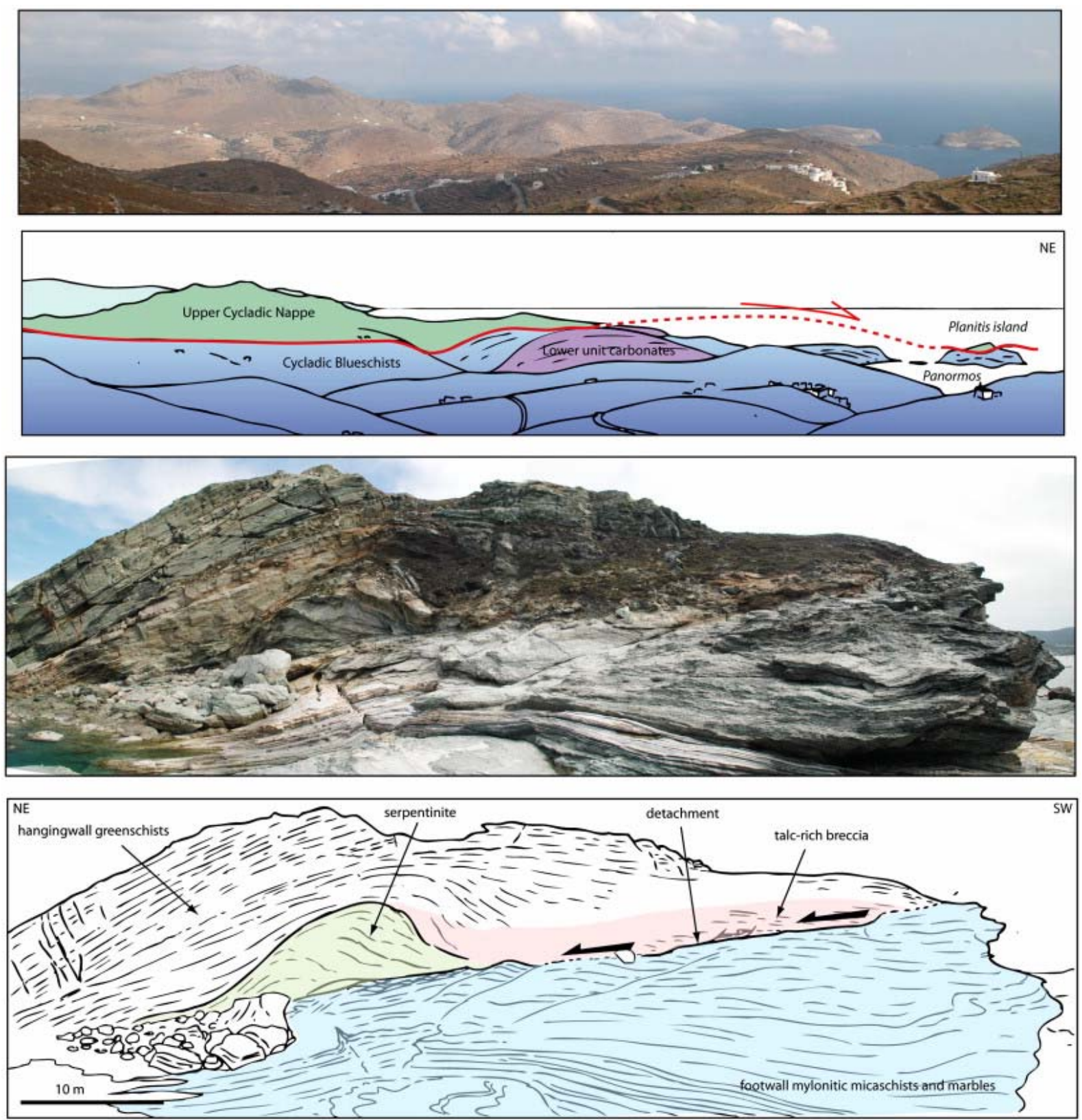

Fig. 6. The Tinos Detachment on Tinos. Upper: panorama of Mt Profitis Ilias and Panormos Bay and its interpretation. The Tinos detachment runs at the base of the Upper Cycladic Nappe and reaches the small islet of Planitis. Lower: a view on the detachment on Planitis. 

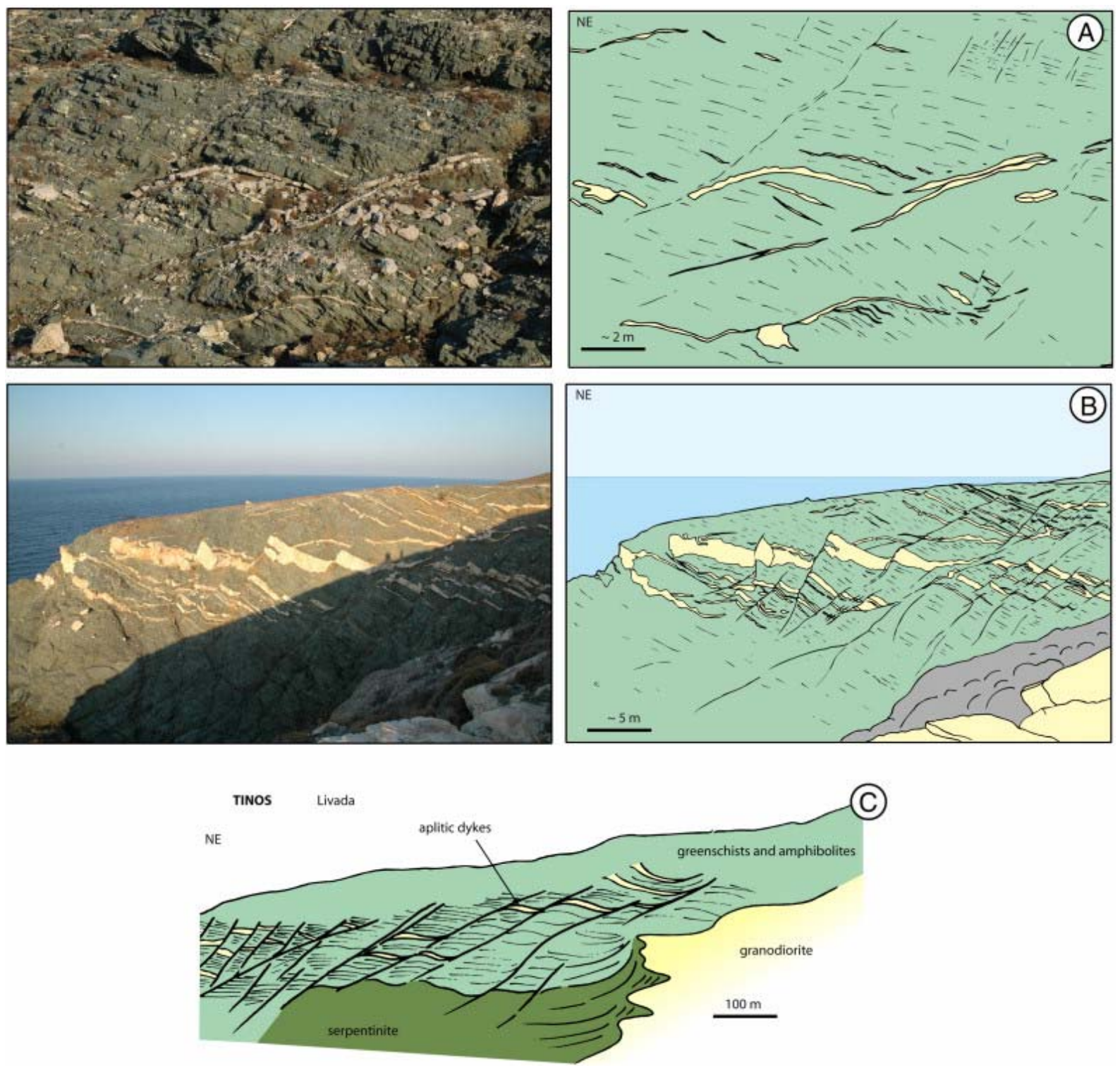

Fig. 7. Ductile and brittle deformations of aplitic sills in the hanging wall of the Tinos detachment on Tinos Island, near Livada beach. A: Aplitic sills intrude the foliation and shear planes in amphibolites. B: sills are offset by a set of steep and shallow-dipping faults all dipping to the North-East. $\mathrm{C}$ : an interpretation of the intrusive relations between the granite and the Upper Cycladic Nappe and of the deformation in the metabasites. 

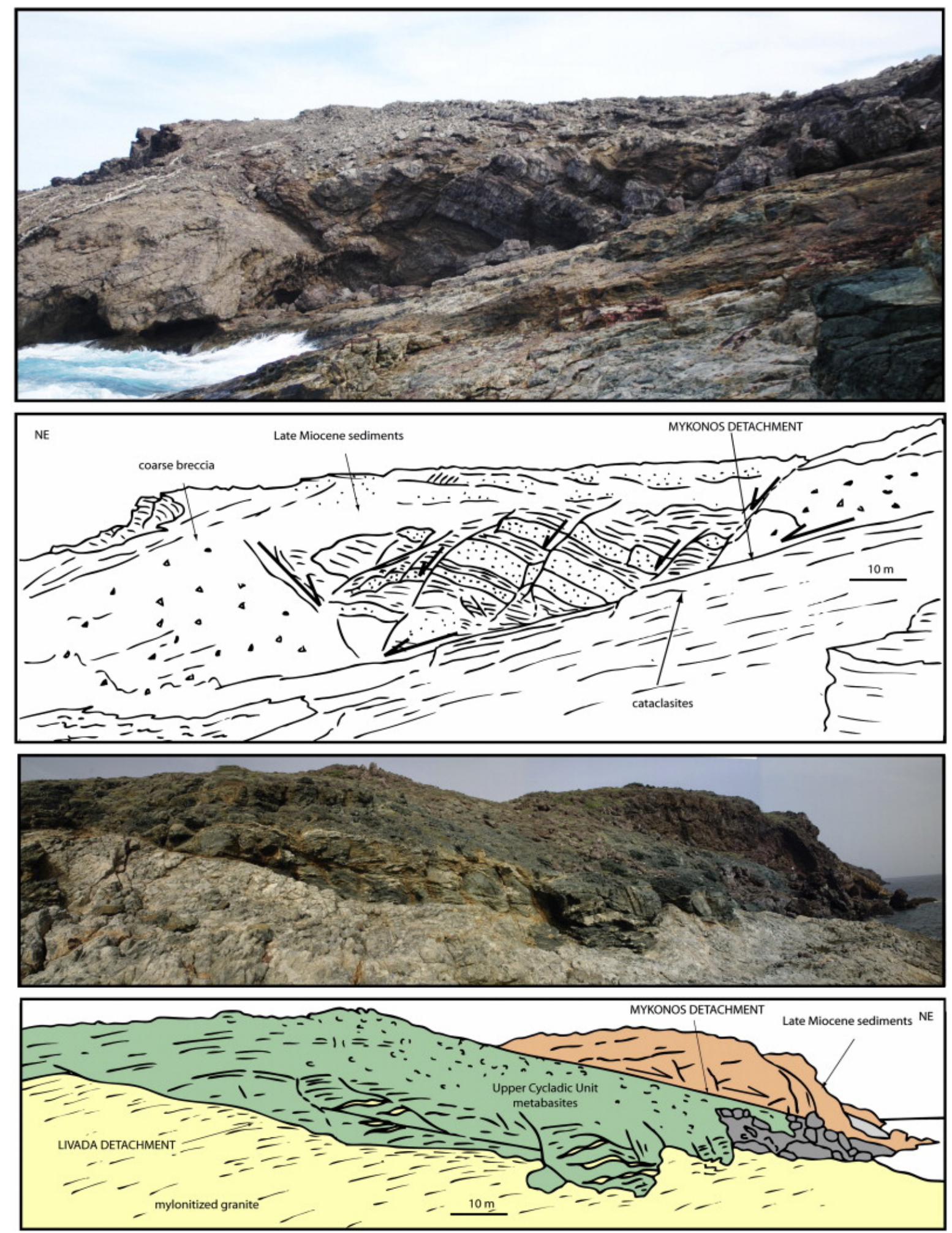

Fig. 8. Photographs of the Mykonos detachment in eastern Mykonos. Upper: view of the western side of cape Evros showing the shallow-dipping detachment surface, the basal breccia, some tilted sandstones and conglomerates and steep normal faults rooting on the detachment. Lower: view of the eastern side of cape Evros showing the sheared intrusive contact between the granite and the dark metabasites (Livada Detachment) and the shallowdipping contact between the metabasites and the coarse breccia and sediments above (Mykonos Detachment). 

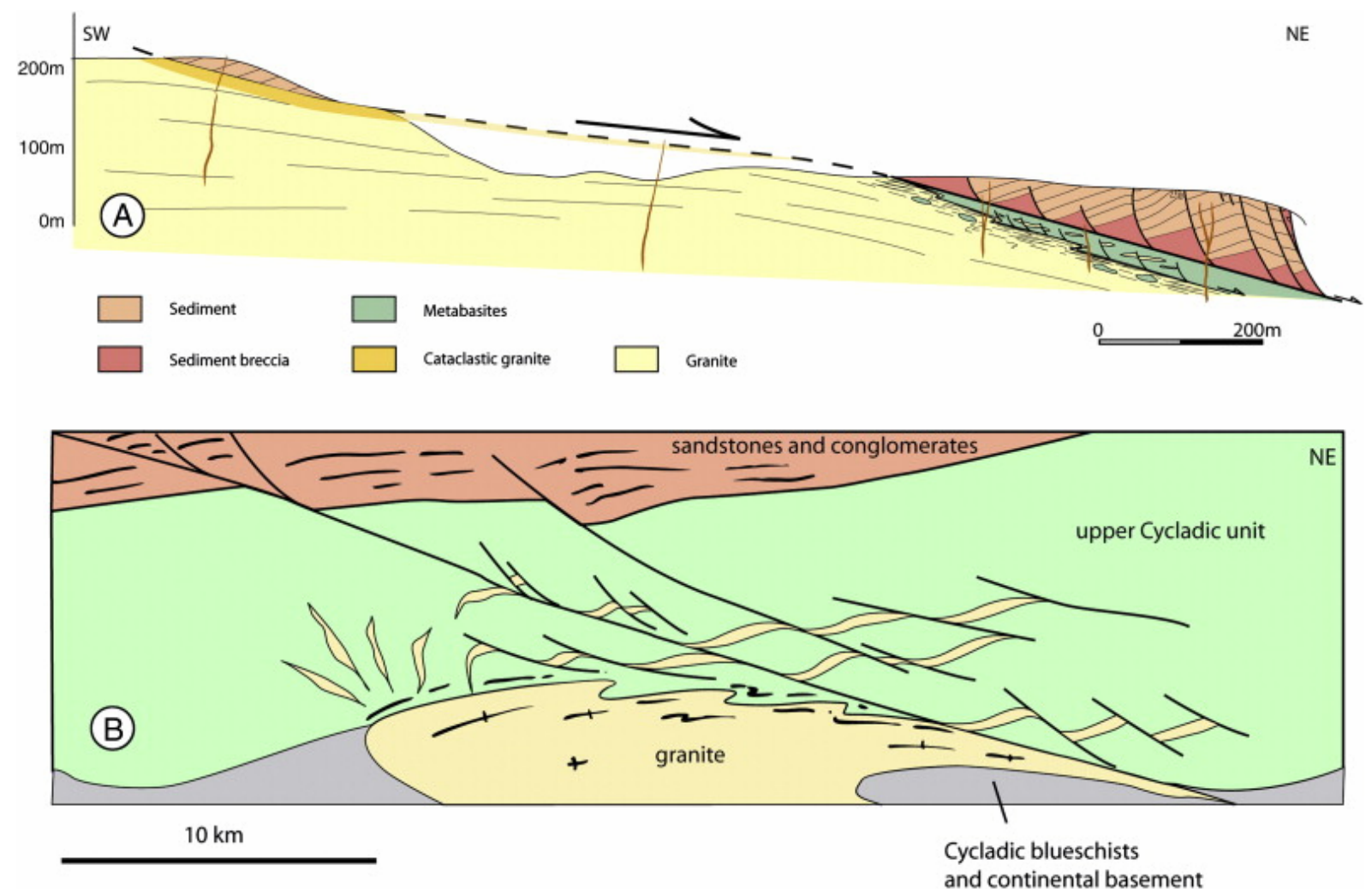

Fig. 9. The relations between the Mykonos granite, the detachments and the late Miocene sediments. A: cross-section of Cape Evros parallel to the stretching direction showing the two detachment surfaces, the cataclasites and the attitude of sediments above the Mykonos detachment. B: interpretative cross-section of Mykonos area at the time of intrusion. The granite induces an uplift of the brittle-ductile transition. The intrusive contact is sheared below the extending Upper Cycladic Nappe. Aplitic sills are sheared by shallow-dipping and steeply-dipping faults and shear zones and sediments are progressively deposited during extension and they are brought in close contact with the lower part of the Upper Cycladic Nappe or the granite as a result of a large displacement along the detachments. 

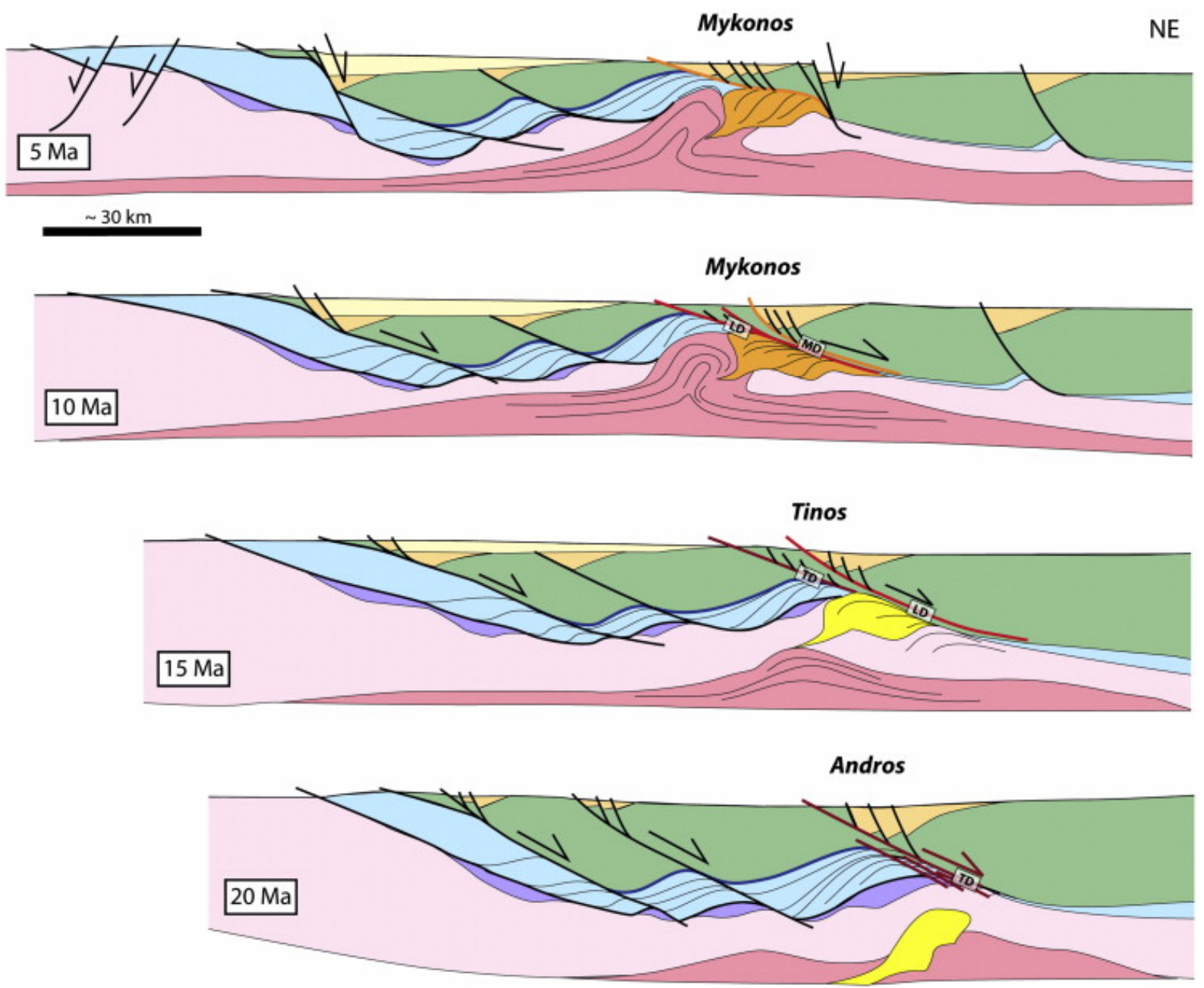

MD Mykonos Detachment

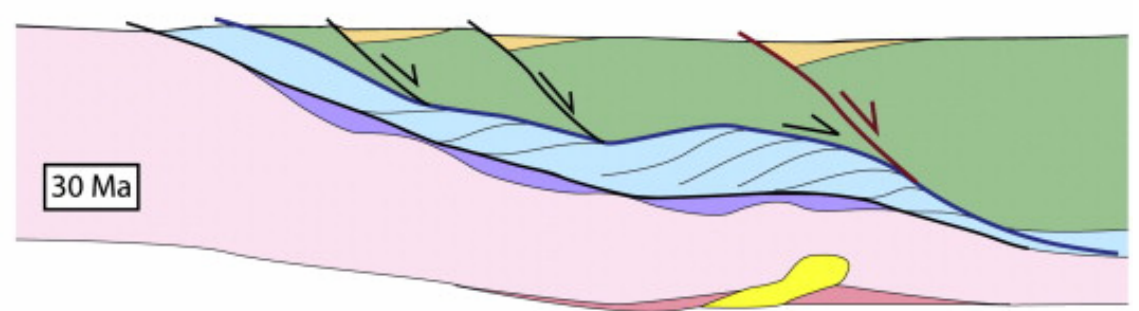

LD Livada Detachment

TD Tinos Detachment

VD Vari Detachment
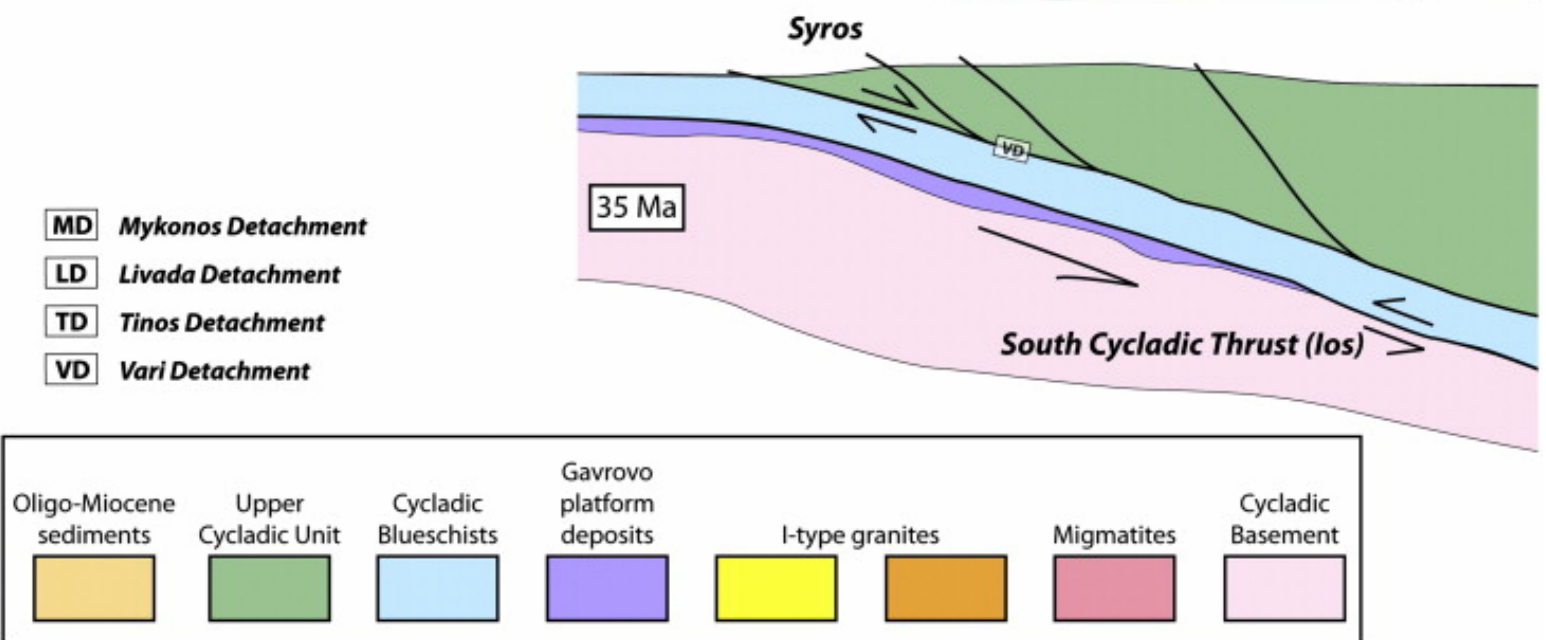

Fig. 10. A possible scenario for the evolution of the NCDS. 